\title{
Silage review: Recent advances and future uses of silage additives ${ }^{1}$
}

\author{
R. E. Muck, ${ }^{* 2,3}$ E. M. G. Nadeau,† T. A. McAllister,‡ F. E. Contreras-Govea,§ M. C. Santos,\# and L. Kung Jr.II \\ *US Dairy Forage Research Center, USDA, Agricultural Research Service, Madison, WI 53706 \\ †Department of Animal Environment and Health, Swedish University of Agricultural Sciences, 53223 Skara, Sweden \\ $\ddagger$ Agriculture and Agri-Food Canada Research Centre, Lethbridge, Alberta, Canada T1J 4B1 \\ §Department of Dairy Science, University of Wisconsin-Madison, Madison, WI 53706 \\ \#Lallemand Animal Nutrition, 74923-090 Aparecida de Goiânia, Goiás, Brazil \\ IDepartment of Animal and Food Sciences, University of Delaware, Newark 19716
}

\begin{abstract}
Additives have been available for enhancing silage preservation for decades. This review covers research studies published since 2000 that have investigated the efficacy of silage additives. The review has been divided into 6 categories of additives: homofermentative lactic acid bacteria (LAB), obligate heterofermentative LAB, combination inoculants containing obligate heterofermentative $\mathrm{LAB}$ plus homofermentative $\mathrm{LAB}$, other inoculants, chemicals, and enzymes. The homofermentative $\mathrm{LAB}$ rapidly decrease $\mathrm{pH}$ and increase lactic acid relative to other fermentation products, although a meta-analysis indicated no reduction in $\mathrm{pH}$ in corn, sorghum, and sugarcane silages relative to untreated silages. These additives resulted in higher milk production according to the meta-analysis by mechanisms that are still unclear. Lactobacillus buchneri is the dominant species used in obligate heterofermentative LAB silage additives. It slowly converts lactic acid to acetic acid and 1,2-propanediol during silo storage, improving aerobic stability while having no effect on animal productivity. Current research is focused on finding other species in the Lb. buchneri group capable of producing more rapid improvements in aerobic stability. Combination inoculants aim to provide the aerobic stability benefits of $L b$. buchneri with the silage fermentation efficiency and animal productivity benefits of homofermentative LAB. Research indicates that these products are improving aerobic stability, but feeding studies are not yet sufficient to make conclusions about effects on animal performance. Novel non-LAB species have been studied as potential silage inoculants. Streptococcus bo$v i s$ is a potential starter species within a homofermentative LAB inoculant. Propionibacterium and Bacillus
\end{abstract}

Received September 14, 2017.

Accepted December 1, 2017.

${ }^{1}$ This article is part of a special issue on silage management.

${ }^{2}$ Corresponding author: remuck@wisc.edu

${ }^{3}$ Retired. species offer improved aerobic stability in some cases. Some yeast research has focused on inhibiting molds and other detrimental silage microorganisms, whereas other yeast research suggests that it may be possible to apply a direct-fed microbial strain at ensiling, have it survive ensiling, and multiply during feed out. Chemical additives traditionally have fallen in 2 groups. Formic acid causes direct acidification, suppressing clostridia and other undesired bacteria and improving protein preservation during ensiling. On the other hand, sorbic, benzoic, propionic, and acetic acids improve silage aerobic stability at feed out through direct inhibition of yeasts and molds. Current research has focused on various combinations of these chemicals to improve both aerobic stability and animal productivity. Enzyme additives have been added to forage primarily to breakdown plant cell walls at ensiling to improve silage fermentation by providing sugars for the LAB and to enhance the nutritive value of silage by increasing the digestibility of cell walls. Cellulase or hemicellulase mixtures have been more successful at the former than the latter. A new approach focused on Lb. buchneri producing ferulic acid esterase has also had mixed success in improving the efficiency of silage digestion. Another new enzyme approach is the application of proteases to corn silage to improve starch digestibility, but more research is needed to determine the feasibility. Future silage additives are expected to directly inhibit clostridia and other detrimental microorganisms, mitigate high mycotoxin levels on harvested forages during ensiling, enhance aerobic stability, improve cell wall digestibility, increase the efficiency of utilization of silage nitrogen by cattle, and increase the availability of starch to cattle. Key words: silage, inoculant, enzyme, formic acid, propionic acid

\section{INTRODUCTION}

For decades, producers have had a wide variety of silage additives available to assist in forage preservation. Silage additives generally fall into one or more of 4 cat- 
egories based on their effects on silage preservation: (1) fermentation stimulants, (2) fermentation inhibitors, (3) aerobic deterioration inhibitors, and (4) nutrients and absorbents (McDonald et al., 1991; Kung et al., 2003a). McDonald et al. (1991) and Kung et al. (2003a) provide extensive reviews of silage additives from a European and North American perspective, respectively. Their reviews cover both additives that are currently in use as well as ones that have diminished in practice.

The aim of the current review is to summarize new research results on silage additives published since the review of Kung et al. (2003a). For those products that have been on the market for a long time, such as formic acid and homofermentative lactic acid bacteria (LAB), the emphasis has been placed on new information regarding their benefits rather than a full review. The reader is encouraged to consult earlier reviews for more information on these additives. In contrast, more complete reviews are presented for silage additives that were nascent at or did not exist before the beginning of the 21st century.

Silage additives can have more than 1 mode of action based on the 4 categories above. In addition, the above categorization focuses on effects largely within the silo; however, the effects of these additives on livestock are often more important to the producer to merit their use. Thus, this review has been divided into 6 groups of additives from a practical perspective of a producer: homofermentative LAB, obligate heterofermentative $\mathrm{LAB}$, combination inoculants containing obligate heterofermentative LAB plus homofermentative or facultative heterofermentative LAB, other inoculants (nonLAB species), chemicals, and enzymes. Within each group, we will discuss effects on silage fermentation, aerobic stability, and livestock intake and utilization. We conclude with what we see as future opportunities for additives to improve silage fermentation characteristics and feed nutritional value and to minimize losses.

\section{HOMOFERMENTATIVE LAB}

\section{Effects on Silage Fermentation}

The oldest and most common bacterial inoculants for making silage are the homofermentative LAB. Today most of the bacteria in this group are recognized taxonomically as facultative heterofermentative LAB species rather than obligate homofermentative species (Pahlow et al., 2003). The facultative heterofermentative LAB ferment hexoses, such as glucose, the same as obligate homofermenters, producing almost exclusively lactic acid. This is in contrast to obligate heterofermenters that produce other compounds from hexoses in addition to lactic acid. The facultative het- erofermenters differ from obligate homofermenters by possessing phosphoketolase. This enzyme allows facultative heterofermenters to ferment pentoses, producing primarily lactic and acetic acids. Common facultative heterofermentative strains include Lactobacillus plantarum, Lactobacillus casei, Enterococcus faecium, and various Pediococcus species. Silages treated with one or more of these bacteria are often lower in $\mathrm{pH}$, acetic acid, butyric acid, and ammonia-N but higher in lactic acid content and exhibit better DM recovery compared with untreated silages (Muck and Kung, 1997). A recent meta-analysis of 130 articles revealed that the effects of these inoculants varied by crop (Oliveira et al., 2017). Inoculation reduced the $\mathrm{pH}$ of silages in temperate and tropical grasses and in alfalfa and other legumes, but not in corn, sorghum, and sugarcane. The reduction in acetic acid by inoculation was significant for all crops except for alfalfa and other legumes. Dry matter recovery was 2.8 percentage units higher in grass silages compared with untreated, unaffected corn and sorghum silages, and reduced by 2.4 percentage units in sugarcane silage. In contrast, the reduction in butyric acid and ammonia- $\mathrm{N}$ and the increase in lactic acid from inoculation were unaffected by forage type.

\section{Effects on Animal Production}

Animal trials have also revealed that these bacteria have not only enhanced silage fermentation but also have improved milk production, daily gain, or feed efficiency (Weinberg and Muck, 1996). A recent metaanalysis of 31 lactating dairy cattle studies indicated that inoculation with homofermentative or facultative heterofermentative LAB increased raw milk production $(0.37 \mathrm{~kg} / \mathrm{d} ; P<0.01)$, with only a trend for increased DMI and no effect on feed efficiency (Oliveira et al., 2017). Trends were observed for increased milk fat and milk protein concentrations for cows fed inoculated silage. Milk production increases by inoculation were not affected by forage type, inoculant species, or level of milk production.

Improvements in animal performance from feeding inoculated silage are difficult to explain. In some studies, changes in common silage characteristics due to silage inoculant use cannot explain the magnitude of improvements in milk production observed (Muck et al., 2013). In other cases, there are experiments where the inoculant did not affect silage fermentation compared with untreated silage, even though inoculation increased animal productivity (Kung and Muck, 2015).

Several hypotheses exist on the cause of improved animal performance, including inhibition of detrimental microbes and toxin production (Ellis et al., 2016b), interaction of LAB with rumen microbes, and alteration 
of rumen fermentation (Weinberg et al., 2003). Regarding the inhibition of detrimental microbes, Ström et al. (2002) found a strain of Lb. plantarum (MiLAB 393) capable of producing a compound that inhibited the growth of some yeasts and molds. In another study, Amado et al. (2012) observed that 1 bacteriocinogenic strain of Pediococcus acidilactici promoted the disappearance of Listeria DNA in corn and ryegrass silages. Those authors also observed that the combination of this strain with $L b$. plantarum proved to be highly effective in ryegrass silages, as this treatment was able to eliminate Listeria DNA during ensiling. Under tropical conditions, Santos et al. (2013) observed that corn silage inoculated with 1 strain of $L b$. plantarum originally isolated from sugarcane silage lacked Listeria spp., whereas the untreated control and corn silages inoculated with other $L b$. plantarum strains had Listeria spp. present.

Recent studies have also investigated differences in the in vitro ruminal fermentations of some inoculated versus untreated silages. For example, Jalc et al. (2009) inoculated grass silage with strains of E. faecium or Lb. plantarum and found significant reductions in in vitro $\mathrm{CH}_{4}$ production (mol of $\mathrm{CH}_{4} / \mathrm{kg}$ of digested DM) for all LAB-treated silages compared with grass silage made without treatment. In another in vitro study, Contreras-Govea et al. (2011) reported that alfalfa and corn silages inoculated with strains of $L b$. plantarum or Lactococcus lactis consistently yielded more rumen microbial biomass than the corresponding untreated silages.

\section{Effects on Aerobic Stability}

One potential issue with homofermentative or facultative heterofermentative LAB inoculants is a reduction in bunk life or aerobic stability in some cases. Muck and Kung (1997) reported that homofermentative inoculants reduced aerobic stability in about a third of the studies they summarized. This occurred more in corn silage than in grass or legume silage. The recent meta-analysis, Oliveira et al. (2017) found that aerobic stability was not affected by inoculation nor was there any effect by crop. However, yeast count was higher in inoculated silages than in untreated silages. Because yeasts are commonly the initiators of aerobic deterioration (Pahlow et al., 2003), higher yeast counts may explain the occasional reduced aerobic stability of silages inoculated with homofermentative LAB. Reduced acetic acid concentrations from inoculation with homofermentative LAB may also contribute to faster yeast growth rates and, thus, reduced aerobic stability. Overall, more research is needed to understand why ho- mofermentative $\mathrm{LAB}$ results are not consistent among all studies.

\section{OBLIGATE HETEROFERMENTATIVE LAB}

Heterofermentative (facultative and obligate) LAB belong to the Lactobacillaceae family and are from the genera Lactobacillus, Oenococcus, Leuconostoc, and Weissella (Hammes and Hertel, 2009). The genus Lactobacillus is divided into 4 groups known as the Lactobacillus buchneri group, the Lb. plantarum group, the Lactobacillus reuteri group, and the Lb. casei group (Hammes and Hertel, 2009). Both the Lb. buchneri and $L b$. reuteri groups contain obligate heterofermenters, but the former has been the sole source of obligate heterofermentative strains studied as potential silage inoculants. The $L b$. buchneri group includes species $L b$. buchneri, Lb. diolivorans, Lb. farraginis, Lb. hilgardii, Lb. kefiri, Lb. kisonensis, Lb. otakiensis, Lb. parabuchneri, Lb. parafarraginis, Lb. parakefiri, Lb. rapi, Lb. sunkii (Hammes and Hertel, 2009; Sun et al., 2014), Lb. ferintoschensis (Hammes and Hertel, 2009), Lb. senioris (Feichtinger et al., 2016), Lb. kunkeei, Lb. homohiochii, $L b$. fructivorans, $L b$. sanfranciscensis, $L b$. lindneri, $L b$. spicheri, Lb. namurensis, Lb. zymae, Lb. acidifarinae, Lb. hammesii, and Lb. brevis (Pot and Tsakalidou, 2009). However, only a few species from the $L b$. buchneri group have been evaluated for their effects on silage fermentation, including primarily $L b$. buchneri and much less commonly $L b$. brevis, $L b$. diolivorans, $L b$. hilgardii, Lb. kefiri, and, recently, Lb. parafarraginis.

\section{Lactobacillus buchneri as a Silage Additive}

In the mid 1990s, Muck (1996) suggested that the addition of $L b$. buchneri to silages might prove valuable in improving aerobic stability because it resulted in moderate increases in acetic acid that had the potential to inhibit yeasts responsible for initiating aerobic spoilage. This suggestion and the research that followed raised much debate, because its classification as a heterolactic acid bacterium went against the dogma of solely using homolactic acid bacteria as silage inoculants. Oude Elferink et al. (2001), however, showed that the increase in acetic acid was not via the classical phosphoketolase pathway but via the anaerobic conversion of moderate amounts of lactic to acetic acid and 1,2-propanediol via the proposed pathway in Figure 1. Lactobacillus buchneri was initially thought to be unable to further metabolize 1,2-propanediol to propanol and propionic acid. Several organisms, including $L b$. diolivorans (Krooneman et al., 2002) and Lb. reuteri (Sriramulu et al., 2008), have this capability; however, recently, Zielinska 

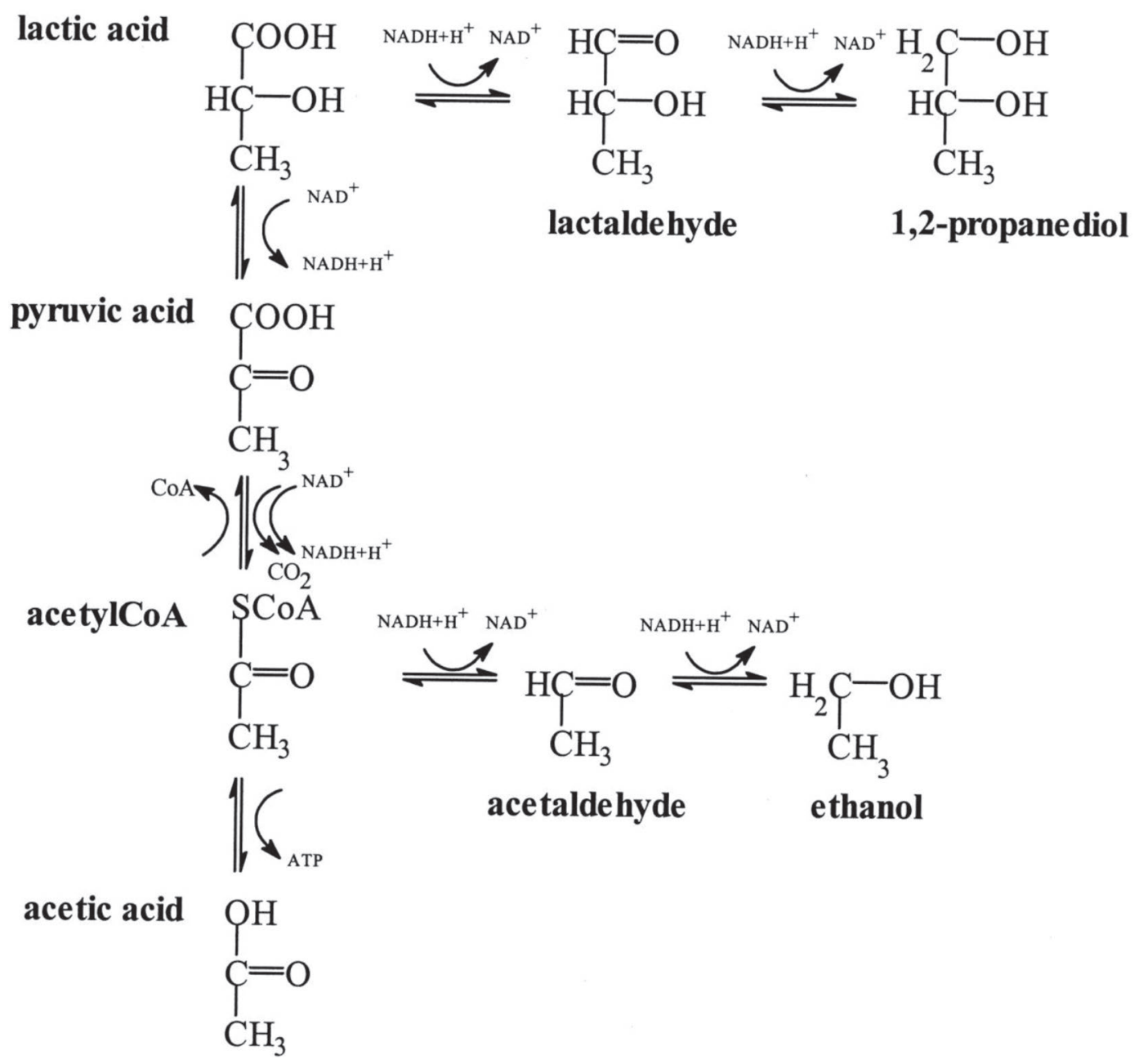

Figure 1. Proposed pathway for anaerobic degradation of lactic acid by Lactobacillus buchneri into equimolar amounts of 1,2-propanediol and acetic acid and trace amounts of ethanol (Oude Elferink et al., 2001; Appl. Environ. Microbiol., 67:125-132. https://doi.org/10.1128/ AEM.67.1.125-132.2001; reproduced with permission from the American Society for Microbiology).

et al. (2017) reported that the novel strain Lb. buchneri A KKP 2047p was also able to metabolize 1,2-propanediol to propionic acid, and that this was facilitated in the presence of glucose and cobalamin. Cobalamin is a cofactor of diol dehydratase, needed for the metabolism of glycerol to 1,3-propanediol and 1,2-propanediol to propionic acid (Lee and Abeles, 1963). It is unknown if naturally occurring strains of $L b$. buchneri in silage have the ability to make this conversion.

Since its introduction as a microbial inoculant for silages, numerous laboratory (e.g., Weinberg et al., 1999; Driehuis et al., 1999; Ranjit and Kung, 2000) and field studies (e.g., Mari et al., 2009; Kristensen et al., 2010; Tabacco et al., 2011) have shown that Lb. buchneri successfully improves the aerobic stability of a variety of silages; however, the effects are strain-specific (Muck, 2004; Kleinschmit et al., 2005) and dose-dependent (Ranjit and Kung, 2000; Taylor and Kung, 2002; Filya et al., 2006). The meta-analysis by Kleinschmit and Kung (2006a) reports that aerobic stability of untreated corn silage was $25 \mathrm{~h}$, whereas it was $35 \mathrm{~h}$ for corn silage treated with $\leq 100,000 \mathrm{cfu}$ of $\mathrm{Lb}$. buchneri/g of fresh forage, but $503 \mathrm{~h}$ for corn silage treated with $>100,000$ cfu of Lb. buchneri/g of fresh forage. Under current commercial settings, formulations with Lb. buchnerican be found with a wide range of final application rates, ranging from about 100,000 to 400,000 cfu/g of fresh forage and up to $600,000 \mathrm{cfu} / \mathrm{g}$ for high-moisture corn. Concerns relative to large losses of DM from a heterolactic acid fermentation and negative effects on DMI due to high levels of acetic acid have generally been proven to be unwarranted. Although the meta-analysis grouping of studies where $L b$. buchneri was added at more than 100,000 cfu/g of forage showed a decreased DM recovery in corn silages by about 1 percentage unit (Kleinschmit and Kung, 2006a), several of the studies 
Table 1. Dry matter intake $(\mathrm{kg} / \mathrm{d})$ from studies feeding silages treated with Lactobacillus buchneri ${ }^{1}$

\begin{tabular}{lccl}
\hline & \multicolumn{2}{c}{ Treatment } & \\
\cline { 2 - 3 } Reference & Control & Lb. buchneri & Crop \\
\hline Dairy cow trials & 28.5 & 28.6 & Whole-plant corn \\
Kung et al., 2010 & 19.4 & 19.6 & Whole-plant corn \\
Adesogan, 2008 & 22.3 & 23.5 & Sugarcane \\
Queiroz et al., 2008 & 19.6 & 19.8 & High-moisture corn \\
Kendall et al., 2002 & 19.3 & 19.7 & High-moisture corn \\
Kendall et al., 2002 & 25.1 & 25.4 & Alfalfa \\
Kung et al., 2003b & 18.6 & 18.5 & Barley \\
Taylor et al., 2002 & 25.1 & 25.4 & Whole-plant corn \\
Driehuis et al., 1999 & 8.7 & 9.6 & Sugarcane (heifers) \\
Pedroso et al., 2006 & & & \\
Sheep trials & 1.24 & 1.28 & Potato hash \\
Nkosi et al., 2010 & 0.79 & 0.92 & Whole-plant corn \\
Nkosi et al., 2009 & 0.90 & 0.94 & Whole-plant corn \\
Ranjit et al., 2002 & & &
\end{tabular}

${ }^{1}$ Modified from Schmidt et al. (2017), with permission.

in that grouping applied more than the highest recommended commercial dose $(400,000 \mathrm{cfu} / \mathrm{g}$ of fresh forage). Small increases in fermentative DM losses can be readily accepted if offset by substantial improvements in aerobic stability of silage during feed out.

In 12 studies, DMI did not differ when dairy cattle or sheep were fed silages untreated or ensiled with $L b$. buchneri (Table 1). In a field summary involving 39 farms in Denmark, Kristensen et al. (2010) reported no detrimental effect of silage inoculated with $L b$. buchneri 40788 on the intake, milk production, health, or reproduction of dairy cows. Rabelo et al. (2016) summarized the effect of 107 treatment means from 29 studies that assessed sugarcane silage treated with $L b$. buchneri, Lb. brevis, Lb. kefiri, and Lb. hilgardii. That summary showed that treating sugarcane silage with obligate heterolactic acid bacteria resulted in higher concentrations of acetic acid, decreased numbers of yeasts, and improved aerobic stability compared with untreated silage.

In addition to improved aerobic stability, some strains of Lb. buchneri are capable of producing ferulic acid esterase in silage with the potential to enhance fiber digestibility (Nsereko et al., 2008). However, the effects have been inconsistent (Hofherr et al., 2008; Kang et al., 2009; Jin et al., 2015, 2017), and factors that might contribute to the ability of these organisms to express significant amounts of this enzyme to produce the desired effect in silage are not understood.

\section{Other Obligate Heterofermentative $L A B$ as Silage Additives}

An area for improvement with inoculants based on $L b$. buchneri is the rapidity of its effects on aerobic stability, because producers often must feed forages within weeks or even days of ensiling. Data suggest that anaerobic conversion of lactic acid to acetic acid by $L b$. buchneri does not occur immediately and needs about 30 to $60 \mathrm{~d}$ to become apparent. Driehuis et al. (1999) applied Lb. buchneri at $5 \times 10^{5} \mathrm{cfu} / \mathrm{g}$ to corn silage. At $14 \mathrm{~d}$, no differences were present in concentrations of lactic and acetic acids between treated and untreated control, but at $28 \mathrm{~d}$ acetic acid was increasing and lactic acid was beginning to decrease in the Lb. buchneri treatment. Schmidt et al. (2009) reported that when Lb. buchneri 40788 was added to alfalfa, 1,2-propanediol (as an indicator of lactic acid to acetic conversion) was not detectable after $5 \mathrm{~d}$ of fermentation but was present at $45 \mathrm{~d}$. Kleinschmit and Kung (2006b) did not detect 1,2-propanediol in corn silage treated with $L b$. buchneri after $28 \mathrm{~d}$ of fermentation, but it was present at $42 \mathrm{~d}$. Similarly, Johanningsmeier and McFeeters (2013) reported that conversion of lactate to 1,2-propanediol did not generally take place until $\geq 21 \mathrm{~d}$ of fermentation in pickles. The reasons for the delayed conversion of lactate to 1,2-propanediol by $L b$. buchneri are unknown, but Oude Elferink et al. (2001) reported that this did not take place until glucose was depleted from growing medium. Daughtry (2015) isolated a wide range of strains of $L b$. buchneri isolated from pickled cucumbers that varied in lactate utilization and growth rates, but we are not aware of similar studies conducted with naturally occurring strains of Lb. buchneri in silages.

To date, several studies have attempted to identify other obligate heterolactic acid bacteria that improve the aerobic stability of silage more rapidly than $L b$. buchneri. For example, Danner et al. (2003) reported that addition of $L b$. brevis slightly improved aerobic stability (72 h until heating) when compared with untreated silage $(40 \mathrm{~h})$, but they added a very high dose 
$\left(7 \times 10^{8} \mathrm{cfu} / \mathrm{g}\right.$ of fresh forage $)$, and improvements in stability were markedly better with $L b$. buchneri (274 h). Addition of $L b$. brevis (strain DSM23231) alone or in combination with Lb. kefiri (strain DSM19455; application rates of $2 \times 10^{5} \mathrm{cfu} / \mathrm{g}$ ) did not affect the concentration of acetic acid, surprisingly increased the numbers of yeasts, and had no effect on aerobic stability compared with untreated sugarcane silage (Daniel et al., 2015). The addition of Lb. hilgardii has shown some promise to alter the fermentation and improve the aerobic stability of silages. In sugarcane silage, Ávila et al. (2014) reported that 2 strains of $L b$. hilgardii (UFLA 51 and 52; now CNCM I-4784 and CNCM I-4785, respectively) resulted in higher concentrations of acetic acid and 1,2-propanediol than in untreated or sugarcane silage treated with strains of $L b$. brevis. Silages treated with the $L b$. hilgardii strains also had lower DM losses and lower concentrations of ethanol and butyric acid as compared with other treatments. However, aerobic stability was not improved in that study, perhaps because of the high residual sugar content of the silage. Assis et al. (2014) added $1 \times 10^{6} \mathrm{cfu}$ of $L$ b. hilgardii per gram of corn forage, and this resulted in improved aerobic stability when compared with untreated silage after 90 but not $30 \mathrm{~d}$ of ensiling. Polukis et al. (2016) added Lb. hilgardii CNCM I-4785 or Lb. buchneri 40788 to high-moisture corn at a final application rate of $6 \times$ $10^{5} \mathrm{cfu} / \mathrm{g}$ of fresh high-moisture corn. They reported that both organisms resulted in similar increases in production of acetic acid and 1,2-propanediol and lower numbers of yeasts when compared with untreated corn silage. After $10 \mathrm{~d}$ of fermentation the aerobic stability was $22 \mathrm{~h}$ for untreated silage, whereas it increased to 42 $\mathrm{h}$ with $L b$. buchneri and to $56 \mathrm{~h}$ with $L b$. hilgardii. Both organisms resulted in silages that were stable for more than $250 \mathrm{~h}$ after 30 and $90 \mathrm{~d}$ of fermentation compared with 31 to $49 \mathrm{~h}$ of stability for untreated silage. Liu et al. (2014) reported that $L b$. parafarraginis ZH1 and a commercial silage inoculant containing $L b$. buchneri improved aerobic stability equally in oat silage stored at $30^{\circ} \mathrm{C}$, but $L b$. parafarraginis $\mathrm{ZH} 1$ provided better stability than $L b$. buchneri in silage stored at $15^{\circ} \mathrm{C}$. Recently, Costa et al. (2017) isolated Lb. parafarraginis from corn silage in Brazil and showed it possessed some antibacterial and antifungal properties.

\section{Modes of Action of Obligate Heterofermentative Bacteria in Improving Aerobic Stability}

To date, the production of acetic acid has been the most accepted explanation of how organisms from the $L b$. buchneri group of bacteria increase the aerobic stability of silages; however, other modes of action may exist. For example, Ström et al. (2002) reported on antifungal compounds [3-phenyllactic acid, 2 dipeptides cyclo (L-Phe-L-Pro) and cyclo (L-Phe-trans-4-OH-LPro)] produced by LAB in silage. Later, Broberg et al. (2007) reported elevated concentrations of antifungal compounds in grass silage treated with LAB inoculants including benzoic acid, catechol, hydrocinnamic acid, salicylic acid, 3-phenyllactic acid, 3-hydroxydecanoic acid, and 4-hydroxybenzoic acid. Ganzorig et al. (2016) isolated $L b$. hilgardii and $L b$. diolivorans strains that had antifungal activity that was deactivated after protease treatment, suggesting that the activity was associated with peptides. Lactobacillus hilgardii has also been shown to produce phenyllactic and 4-hydroxyphenyllactic acids that have antifungal activity (Valerio et al., 2004). Thus, multiple or synergistic effects may account for improvements in aerobic stability beyond that of acetic acid alone. Understanding how and why $L b$. buchneri becomes the dominant LAB in prolonged fermentations in silages (Schmidt et al., 2009) and other fermented foods (although it is undesirable in these cases; Johanningsmeier and McFeeters, 2013) may also help us better understand what characteristics to look for in future microbial inoculants designed to improve the aerobic stability of silages.

\section{COMBINATION INOCULANTS}

\section{Effects on Silage Fermentation}

The development of inoculants that combine facultative and obligate heterofermentative LAB has the goal of achieving the benefits of both types of inoculants in one product. The facultative heterofermentative LAB would control the early active fermentation period, suppressing enterobacteria, clostridia, and other microorganisms, and thus reduce proteolysis and fermentation DM losses. In this active fermentation period, $\mathrm{pH}$ would be expected to drop more rapidly and to a lower value than in untreated silage. The obligate heterofermentative LAB, in most cases Lb. buchneri, would slowly convert lactic acid to acetic acid after the active silage fermentation period, raising $\mathrm{pH}$ and improving the aerobic stability of the silage. Ideally, animal production, whether daily gain or milk production, would be improved by the effect of facultative heterofermentative LAB on production or in keeping the silage cool in the feed bunk.

The 21st century has seen the rise of these inoculants in the laboratory and the marketplace. One of the earliest sets of experiments that combined traditional plus Lb. buchneri inoculants was conducted by Driehuis et al. (2001). Using laboratory silos (both jars and bags), they inoculated perennial ryegrass with $L b$. buchneri alone or in a mixture with Pediococcus pentosaceus 
and $L b$. plantarum, comparing the results to grass that was untreated and treated with $P$. pentosaceus and $L b$. plantarum, negative and positive controls. All strains were commercial strains with proven efficacy in silage. In their initial experiment, silos (jars) were opened at 4 times over the first $14 \mathrm{~d}$, providing a picture of the early stages of silage fermentation. All treatments with $P$. pentosaceus and $L b$. plantarum, including the mixtures with $L b$. buchneri, had the most rapid drop in $\mathrm{pH}$ and the lowest DM losses. Treatments with Lb. buchneri alone had a pH decline similar to the untreated control and DM losses similar to or greater than the untreated control. After $21 \mathrm{~d}$ of fermentation, DM losses in the $L b$. buchneri alone treatments were always greater than those in the untreated control, whereas DM losses in the mixed inoculant treatments were intermediate between those of the untreated control and the positive control, P. pentosaceus and Lb. plantarum.

In the 90-d bag silos used for aerobic stability measurements, elevated acetic acid concentrations occurred only in the Lb. buchneri-alone treatments, whereas the mixtures had levels similar to the control; concentrations in the $P$. pentosaceus and $L b$. plantarum treatment were lower than in control. Relative to the control, all treatments containing $P$. pentosaceus and Lb. plantarum had higher lactic acid contents, whereas Lb. buchneri alone had lower lactic acid concentrations. All inoculant treatments reduced ammonia content. Yeast counts were decreased and aerobic stability was increased in all treatments containing $L b$. buchneri, whereas $P$. pentosaceus and $L b$. plantarum alone decreased aerobic stability.

In 2 subsequent experiments, results similar to the first experiment were observed for the combination inoculant mixtures: more rapid $\mathrm{pH}$ declines and increased aerobic stability relative to the control. With longer storage $(120 \mathrm{~d})$, a greater conversion of lactic acid to acetic acid occurred compared with the first experiment so that fermentation profiles with the combination inoculants were more similar to Lb. buchneri alone. Overall, by using commercial strains in combination, improvements were observed in early fermentation from the $P$. pentosaceus and $L b$. plantarum strains and improvements in aerobic stability with extended storage time from $L b$. buchneri.

Since Driehuis et al. (2001), more than two dozen peer-reviewed reports have been published using combination inoculants in various crops. The sources of combination inoculants have varied, including laboratory strains, commercial strains, or commercial products. Most studies have been in laboratory silos of different types. The length of ensiling has been typically between 90 and $120 \mathrm{~d}$, and most often no measurements have been collected in early fermentation to document the effects of the facultative heterofermentative or homofermentative LAB. Some trials have only compared the combination inoculant against an untreated control so that one cannot be certain how well the product affected aerobic stability compared with treatment with Lb. buchneri alone.

All the published studies have investigated combinations with $L b$. buchneri even though there are combination products where $L b$. brevis is the obligate heterofermenter in the marketplace. Typically, one or more facultative heterofermenter or homofermenter have been paired with $L b$. buchneri, with selected species varying considerably among studies. The most common pairing in the literature has been with Pediococcus pentosaceus (e.g., Sousa et al., 2008; Schmidt and Kung, 2010; Arriola et al., 2011), which was commercialized. Other species used include Lb. plantarum (Filya, 2003), $P$. pentosaceus and Lb. plantarum (Adesogan and Salawu, 2004), Lb. plantarum and Enterococcus faecium (Huisden et al., 2009; Jatkauskas and Vrotniakiene, 2011), Lb. casei (Kang et al., 2009), P. acidilactici (Reich and Kung, 2010), Lb. plantarum and Lb. casei (Addah et al., 2012), P. acidilactici, P. pentosaceus, Lb. plantarum, and E. faecium (Thomas et al., 2013), Lc. lactis (Ellis et al., 2016a), and Lc. lactis and Lb. plantarum (Ellis et al., 2016a). With such a broad spectrum of different species, with variations in relative rates of inclusion of species within inoculants, and with consideration for differences among strains of a given species, it should not be surprising that there are variations in results with combination inoculants.

Only one published study has attempted to compare potential partners for a given $L b$. buchneri strain in a combination inoculant. Reich and Kung (2010) individually compared 3 facultative heterofermentative LAB strains (P. acidilactici, P. pentosaceus, and $L b$. plantarum) paired with a $L b$. buchneri strain on wholeplant corn. All 3 pairs resulted in silages with low or below detectable levels of yeasts and aerobic stabilities greater than $500 \mathrm{~h}$ compared with $180 \mathrm{~h}$ in the untreated control. The inoculants with the Pediococcus strains produced the highest levels of acetic acid and lowest ethanol concentrations. The inoculants with $P$. acidilactici and $L b$. plantarum produced the highest DM recoveries as well as NDF digestibilities that were higher than that of the untreated silage. Although it is unclear why these LAB strains improved NDF digestibility, these results indicate the importance of the strains selected for use in the formulation of a combination inoculant.

Relatively few studies since Driehuis et al. (2001) have focused on the success of the combination inoculant during the first 1 to $2 \mathrm{wk}$ of fermentation. Schmidt et al. (2009) followed fermentation in alfalfa silage 
untreated or treated with $L b$. buchneri or $L b$. buchneri plus $P$. pentosaceus. The $\mathrm{pH}$ over the first $5 \mathrm{~d}$ was higher with $L b$. buchneri inoculation compared with the untreated silage, whereas the combination inoculant produced a faster $\mathrm{pH}$ decline than untreated silage. Addah et al. (2012) compared a combination inoculant containing Lb. buchneri, Lb. plantarum, and Lb. casei with an untreated control in whole-crop barley silage; in laboratory silos, the combination inoculant had a more rapid $\mathrm{pH}$ decline in the first week of ensiling. Arriola et al. (2015) compared 4 commercial inoculants versus untreated for making bermudagrass silage in wrapped round bales at approximately 50\% DM. One of the inoculants was a combination inoculant containing Lb. buchneri and P. pentosaceus. It had the fastest rate of $\mathrm{pH}$ decline over 7 and $30 \mathrm{~d}$; however, an inoculant from the same company containing $P$. pentosaceus and Propionibacterium freudenreichii performed similarly. These results indicate that a combination inoculant is capable of dominating the early stages of fermentation, causing a more rapid decline in $\mathrm{pH}$ compared with untreated silage.

\section{Effects on Aerobic Stability}

At some point during storage, Lb. buchneri populations begin to rise and cause changes in $\mathrm{pH}$ and silage fermentation characteristics. Schmidt et al. (2009) was the first to use real-time quantitative PCR to follow the $L b$. buchneri population in alfalfa silage untreated or treated with $L b$. buchneri alone or in a combination inoculant that included $P$. pentosaceus. The Lb. buchneri populations were similar at ensiling across all 3 treatments. The Lb. buchneri population rose similarly in both inoculated treatments, achieving $>10^{8} \mathrm{cfu} / \mathrm{g}$ of alfalfa by d 5, whereas it remained low in the untreated silage. By the next sampling time at $45 \mathrm{~d}$, both inoculated treatments showing similar production of 1,2-propanediol, indicating the activity of $L b$. buchneri in fermenting lactic acid.

The eventual domination of the fermentation by $L b$. buchneri with the loss of lactic acid and increase in acetic acid and aerobic stability has been commonly observed in most studies. Thus, it is probably more instructive to look at the few cases where combination inoculants have failed to improve aerobic stability. Adesogan and Salawu (2004) were the first to report the effects of a commercially available combination inoculant containing Lb. buchneri, P. pentosaceus and Lb. plantarum. This inoculant was compared with 3 other treatments (untreated, Lb. buchneri, and formic acid) on 2 pea/ wheat mixtures. Neither inoculant improved aerobic stability relative to those of the untreated silages. In both untreated silages, acetic acid was high (42 and 26 $\mathrm{g} / \mathrm{kg}$ of $\mathrm{DM}$ ) and the combination inoculant failed to increase acetic acid relative to untreated silage. Kang et al. (2009) reported on the effectiveness of a combination inoculant containing Lb. casei and Lb. buchneri in corn silage. With one corn cultivar the inoculant was successful in improving aerobic stability, but in the other cultivar the inoculant reduced aerobic stability compared with untreated silage. In the latter case, fermentation characteristics between inoculated and untreated were similar, suggesting the inoculant may have been overwhelmed by the natural LAB population associated with the corn forage. Arriola et al. (2011) compared Lb. buchneri with or without $P$. pentosaceus in corn silage ensiled for $575 \mathrm{~d}$. The untreated control was aerobically stable $(390 \mathrm{~h}) ;$ Lb. buchneri alone did not improve aerobic stability but had the highest DM recovery of all treatments. The combination inoculant reduced aerobic stability $(276 \mathrm{~h})$ and had an intermediate DM recovery; it was the only treatment with a lactic-to-acetic acid ratio greater than 1.0. It appeared that the untreated silages underwent a Lb. buchneri-like fermentation, with acetic acid concentration 3 times greater than lactic acid. Thomas et al. (2013) studied the effects of a combination inoculant (Lb. buchneri, $P$. acidilactici, $P$. pentosaceus, Lb. plantarum, E. faecium) on 4 sorghum cultivars. The inoculant did not produce silage that was more heterofermentative than the corresponding untreated silage. In fact, in 2 of the 4 cultivars the inoculated silage had a more homofermentative fermentation profile compared with the control; not surprisingly, this inoculant did not improve aerobic stability in any of the cultivars. The combination of the fermentation and aerobic stability results suggested that the Lb. buchneri portion of this inoculant did not contribute to the fermentation for whatever reason, even though the silages were ensiled for $120 \mathrm{~d}$, a duration sufficient for $L b$. buchneri to exhibit activity. Overall, failures of combination inoculants may arise from either the natural population exhibiting significant $L b$. buchneri-like activity or the Lb. buchneri strain in the inoculant failing for some reason to dominate the latter stages of fermentation.

\section{Effects on Animal Production}

The effect of combination inoculants on animal production is uncertain at this time. The only animal study found (Addah et al., 2012) compared a combination inoculant containing Lb. buchneri, Lb. plantarum, and $L b$. case $i$ with an untreated control in whole-crop barley silage. The $L b$. buchneri strain produced a ferulic acid esterase, theorized to improve fiber digestibility. In laboratory silos at $95 \mathrm{~d}$ of ensiling, silage fermentation characteristics in the inoculated silage were more 
heterofermentative than the control, with a higher $\mathrm{pH}$ and lower lactic-to-acetic acid ratio. The inoculated silage did not heat over $21 \mathrm{~d}$ of aeration, whereas the control heated at $7 \mathrm{~d}$. When fed to growing feedlot steers, intake was reduced with the diet containing the inoculated silage, but gain was similar between the 2 treatments; thus, gain per unit of intake was higher on inoculated silage ( 0.19 vs. $0.17 ; P<0.03)$.

Several studies have measured in situ or in vitro digestibility. Sousa et al. (2008) compared urea, $L b$. buchneri, and a combination inoculant with $L b$. buchneri and P. pentosaceus on sugarcane silage. The combination inoculant produced the highest DM recovery, highest in vitro DM digestibility, and lowest ethanol concentrations, whereas Lb. buchneri alone produced similar characteristics to the untreated silage. Kang et al. (2009) reported on the effectiveness of a combination inoculant containing $L b$. casei and $L b$. buchneri. The Lb. buchneri strain was also capable of producing a ferulic acid esterase that could affect NDF digestibility. With one corn cultivar the inoculant had no effect on in situ DM or NDF digestibility, whereas in the other cultivar the inoculant improved both DM and NDF digestibility. Reich and Kung (2010) found that when $L b$. buchneri was paired with $P$. acidilactici or $L b$. plantarum, their in vitro NDF digestibilities were higher than that of the untreated silage, whereas the pairing of $L b$. buchneri with $P$. pentosaceus produced silage with similar NDF digestibility to that of untreated silage. Thomas et al. (2013) studied the effects of a combination inoculant (Lb. buchneri, P. acidilactici, P. pentosaceus, Lb. plantarum, E. faecium) on 4 sorghum cultivars. In only 1 of the 4 cultivars was in vitro true digestibility increased by the inoculant over that of untreated silage. Ellis et al. (2016a) studied 3 combinations of LAB strains as inoculants on different forages; 2 of the combinations contained $L b$. buchneri (one with Lc. lactis and the other with Lc. lactis and $L b$. plantarum). In only 2 instances was in vitro digestibility affected by the inoculant. In ryegrass baleage the latter inoculant increased OM digestibility by $20 \mathrm{~g} / \mathrm{kg}$ relative to the untreated, with no effect on VFA production or methane as a fraction of gas production. The former combination reduced OM digestibility by $17 \mathrm{~g} /$ $\mathrm{kg}$ in grass/clover silage relative to untreated, shifted VFA production toward acetate, and had no effect on methane production as a fraction of gas production.

Overall, it appears that combination products can be successful in increasing the rate of $\mathrm{pH}$ decline in the first week of fermentation in the silo due to the activity of homofermentative or facultative heterofermentative LAB. Later during storage, $L b$. buchneri ferments lactic acid to acetic acid and other end-products that aerobically stabilize silage as compared with untreated silage.
As with all inoculants, the combination inoculants have not always delivered the above benefits. Some failures may be due to competition from members within the epiphytic population; however, other failures suggest that the pairings of strains in some inoculants may need to be further refined (e.g., Thomas et al., 2013).

It is less clear that current combination inoculants can consistently improve animal production or production efficiency, as insufficient animal feeding studies have been published to draw a conclusion. In vitro and in situ digestibilities indicate that improvements in fiber digestion may be possible, but more work needs to be conducted to determine if similar improvements in fiber digestion occur in vivo. This is a concern, as studies such as Reich and Kung (2010) and Ellis et al. (2016b) suggest that strains that perform similarly in the silo may not necessarily provide similar benefits in the rumen.

\section{OTHER INOCULANTS}

Several novel inoculant approaches have been investigated in recent years; these include Streptococcus bovis, Propionibacterium acidipropionici, Bacillus species, and yeast. The bacterial species have been studied before 2000, and commercial inoculants exist containing Propionibacterium or Bacillus species.

\section{Streptococcus bovis}

Of novel inoculants, $S$. bovis most closely resembles the LAB strains that are used in inoculants. It is a lactic acid bacterial species found in the rumen rather than in silage. It is noted to be one of the fastest growing bacterial species in the rumen, with a doubling time of as little as $20 \mathrm{~min}$, a rate faster than LAB used in ensiling. This makes it an attractive starter strain in an inoculant to rapidly decrease $\mathrm{pH}$ during the early stages of ensiling (Jones et al., 1991). As S. bovis is not as tolerant of low $\mathrm{pH}$ as lactobacilli, its population should decline after active silage fermentation, reducing the likelihood it will enter the rumen with silage. Ferreira et al. (2013) compared $2 S$. bovis strains to untreated and E. faecium-treated, negative and positive controls, on unwilted elephant grass in laboratory silos. After $60 \mathrm{~d}$ of ensiling, both $S$. bovis treatments reduced $\mathrm{pH}$ and ammonia-N and produced a more homofermentative fermentation relative to the other treatments. The $S$. bovis strains reduced both gaseous and effluent losses, resulting in better DM recovery than from either the untreated or E. faecium-treated silages. Thus, both strains showed promise as potential inoculant strains for tropical grass. 


\section{Propionibacterium Species}

Inoculation of silage with Propionibacterium species has the goal of producing propionic acid during ensiling to improve aerobic stability. Filya et al. (2004) noted that previous studies with Pr. acidipropionici and Propionibacterium shermanii had produced mixed results in improving aerobic stability in corn and small grain silages. They studied inoculation with $\mathrm{Pr}$. acidipropion$i c i, L b$. plantarum, or both in wheat, corn, and sorghum silages; the results were similar across all 3 crops. Propionibacterium acidipropionici alone increased acetic and propionic acids relative to the untreated control and produced silages with the least losses over a 5 -d aerobic stability test as measured by $\mathrm{CO}_{2}$ production. After 5 $\mathrm{d}$, yeast counts remained below detectable levels in the Pr. acidipropionici-treated silages. When Pr. acidipropionici and $L b$. plantarum were paired, lactic, acetic, and propionic acid concentrations were similar to the Lb. plantarum-only treatment, which had higher lactic acid content and lower acetic acid content than the control. In the 5 -d aerobic stability test, the combination inoculant produced $\mathrm{CO}_{2}$ losses that were similar to the control but less than $L b$. plantarum-treated silages. Thus, Pr. acidipropionici, when applied alone, was the most successful of all treatments in reducing aerobic losses and maintaining aerobic stability by keeping yeast counts low.

\section{Bacillus Species}

Bacillus subtilis may be a promising species to improve aerobic stability by producing a bacteriocin that inhibits yeasts and molds (Pahlow et al., 2003). Recently, Lara et al. (2016) compared 3 treatments on corn silage (untreated, B. subtilis, and B. subtilis plus $L b$. plantarum). After $96 \mathrm{~d}$ of ensiling, yeast counts were lowest in the B. subtilis treatment, whereas counts were similar in the other 2 treatments. Aerobic stabilities in the B. subtilis and combination treatments were more than 3-fold longer and twice as long, respectively, than in the untreated silage. Additionally, both inoculant treatments improved in vitro apparent OM digestibility by $50 \mathrm{~g} / \mathrm{kg}$.

Two other studies have included treatments containing B. subtilis, but their experimental designs make it more difficult to determine the effects of $B$. subtilis. Gandra et al. (2016) compared 4 treatments (untreated, Lb. buchneri, Lb. buchneri plus B. subtilis, and chitosan) in making sugarcane silage. The addition of B. subtilis produced few differences from the $L b$. buchneri treatment. Gaseous and effluent losses during ensiling were similar between the 2 inoculants but lower than those of the untreated control. In vitro DM and NDF digestibilities were similar between inoculants and control. Acetic acid content was higher and butyric acid was lower in the $L b$. buchneri plus B. subtilis treatment compared with $L b$. buchneri alone. Both inoculants had similar aerobic stabilities that were greater than the control, but the combination produced lower DM losses over a 7-d aeration period than $L b$. buchneri alone. Keles et al. (2010) investigated the effects of various silage additives in making grass silage in wrapped round bales. One of the treatments was a commercial inoculant containing Lb. plantarum, Serratia rubidaea, and B. subtilis. This product did not improve aerobic stability relative to the untreated control.

\section{Yeast}

The recent trials using yeast as a silage inoculant are the most unusual. Yeast, particularly lactate-assimilating yeast, are the primary initiators of aerobic spoilage in silage (Pahlow et al., 2003). However, some yeast species may be beneficial as inoculants in 2 different areas: inhibiting detrimental silage microorganisms and growing yeasts that are currently used as direct-fed microbials (DFM) to the cow.

Pichia anomala is an intriguing yeast species. The J121 strain isolated from high-moisture wheat has shown strong antifungal activity as well as activity against some gram-negative bacteria (Schnürer and Jonsson, 2011). It grows under anaerobic conditions if supplied with ergosterol and UFA. It has been tested primarily in high-moisture wheat at both laboratory and field scale. For example, in high-moisture barley ensiled in bag silos after 5 mo of storage, the inoculated barley had higher yeast counts than untreated (by more than 100 fold), lower mold counts (4\% of untreated), and below detectable levels of enterobacteria (compared with $4.4 \mathrm{log} \mathrm{cfu} / \mathrm{g}$ in untreated; Olstorpe et al., 2010). Inoculated wheat and barley have been fed to chickens and beef cattle, respectively. No negative effects on animal health, growth rate, or feed conversion efficiency have been found (Schnürer and Jonsson, 2011). Even though this yeast strain looks promising, regulatory and other issues have been barriers to commercialization.

More recently, Savage et al. (2014) investigated the effects of 2 strains of Saccharomyces cerevisiae and an unidentified yeast species on ensiling of corn silage. None of the 3 strains affected fermentation or aerobic stability relative to the untreated control. Nevertheless, the success of the Pichia anomala J121 strain suggests that some yeast strains may be beneficial in preventing spoilage and inhibiting the development of other detrimental microorganisms in silage. 
Several studies have investigated applying DFM yeast strains at ensiling. Ok et al. (2006) made rice straw silage with 4 treatments: untreated, Sac. cerevisiae, Humicola grisea, and Candida glabrata. The yeast treatments produced a faster and greater reduction in $\mathrm{pH}$ over $20 \mathrm{~d}$ compared with untreated. Crude protein concentration was also increased by 38 to $41 \%$ by inoculation with yeast. Sofyan et al. (2011) inoculated king grass with 3 inoculant treatments (untreated, $L b$. plantarum, and Lb. plantarum plus Sac. cerevisiae) along with 3 different levels of rice bran $(0,5$, and $10 \%)$. After $21 \mathrm{~d}$ of ensiling, the $L b$. plantarum plus Sac. cerevisiae treatment had the highest yeast counts and lowest clostridial counts. In vitro ruminal digestion over $48 \mathrm{~h}$ measured by gas production was greatest for the $L b$. plantarum treatment and intermediate for $L b$. plantarum plus Sac. cerevisiae treatment. Volatile fatty acid profiles and ammonia concentrations in the rumen fluid were not affected by treatment. Both studies used short ensiling periods and did not report fermentation products or aerobic stability.

Duniere et al. (2015) ensiled whole-plant corn comparing 4 treatments: untreated, 2 strains of Sac. cerevisiae and 1 strain of Saccharomyces paradoxus. After $90 \mathrm{~d}$ of ensiling, silage $\mathrm{pH}$ and fermentation product concentrations were not different across treatments. In situ and in vitro analyses of the 90-d silages did not show any differences among the treatments for DM disappearance, gas production, or microbial protein synthesis. Yeast counts with 1 Sac. cerevisiae treatment (S1) were higher than the control, and S1 also aerobically deteriorated more rapidly than the control; the other 2 yeast treatments were similar to the control in yeast counts and aerobic stability. Using real-time quantitative PCR, Duniere et al. (2015) were able to track Saccharomyces at both the genus and species level. With all 3 yeast treatments, elevated levels of Saccharomyces yeasts were detected through $28 \mathrm{~d}$ of ensiling as compared with the control, but not thereafter. Elevated levels of the species inoculated were observed after ensiling only with S1 and only at d 7. During aerobic exposure, S1 had higher levels of total Saccharomyces and Sac. cerevisiae than the control at d 3 and 7. The silage inoculated with Sac. paradoxus also had higher levels of Saccharomyces than the control after 7 $\mathrm{d}$ of aerobic exposure. These results suggest that it may be possible to apply a DFM strain at ensiling, have it survive ensiling and multiply during feed out.

\section{CHEMICAL ADDITIVES}

Active ingredients in chemical additives are acids and salts. The acids are formic, sorbic, benzoic, propionic, and acetic acids. Depending on application rate and whether buffered, formic acid can cause a direct acidification and suppression of undesired spoilage bacteria, thereby improving the preservation of silage. Sorbic, benzoic, propionic, and acetic acids improve aerobic stability of the silage at feed out through direct inhibition of yeasts and molds (Auerbach et al., 2012). Sorbic acid also can be inhibitory to some bacteria, such as clostridia (Woolford, 1975). The undissociated form of the acids is inhibitory to microorganisms, as this form passes through the cell membranes and releases $\mathrm{H}^{+}$, thus acidifying the cytoplasm. Sorbic acid is a more potent inhibitor of yeasts, molds, and spoilage bacteria than benzoic acid. The greater inhibitory activity of sorbic acid is only partially attributable to its higher acid dissociation constant (4.75) than benzoic acid (4.20), as acids can differ in their antimycotic effects at the same $\mathrm{pH}$ (Auerbach, 1996) because of differences in molecule-specific activity. Shao et al. (2007) documented improved fermentation of perennial ryegrass with decreased concentrations of butyric, acetic, and propionic acids, ethanol, and $\mathrm{NH}_{3}-\mathrm{N}$ in silage treated with $0.1 \%$ sorbic acid compared with untreated silage. The salts calcium formate, sodium formate, ammonium formate, sodium nitrite, and hexamethylene tetramine (hexamine) improve silage fermentation by suppressing spoilage bacteria. The salts sodium benzoate, potassium sorbate, ammonium propionate, calcium propionate, sodium propionate, and sodium acetate inhibit yeasts and molds by release of the respective acid in silage, thereby improving aerobic stability (Auerbach et al., 2012). To achieve a broad spectrum of activity against spoilage bacteria and fungi, commercial additives often contain mixtures of these active ingredients at various concentrations.

\section{Effects on Silage Fermentation}

Formic Acid-Based Additives. Application of formic acid-based additives in mixtures with ammonium formate at 3 to $6 \mathrm{~L} / \mathrm{t}$ to direct cut or wilted grass silages causes a drop in the $\mathrm{pH}$ by direct acidification, restricts fermentation of water-soluble carbohydrates (WSC), and reduces acetic acid concentration and proteolysis (e.g., Saarisalo et al., 2006; Conaghan et al., 2011; Seppälä et al., 2016). In addition to these effects, Lindqvist et al. (2011) measured a decline in lactic acid and ethanol contents when a formic/propionic acid-based additive was applied at $5 \mathrm{~L} / \mathrm{t}$ to red clover (85\%)/grass (15\%) and birdsfoot trefoil (65\%)/grass (35\%) silage at 25 to $30 \%$ DM. Similar results were found when the same additive was applied at $4 \mathrm{~L} / \mathrm{t}$ to whole-crop cereals (Nadeau, 2007) or when formic acid at $2 \mathrm{~L} / \mathrm{t}$ was applied to pea/wheat silages (Adesogan and Salawu, 2004). However, König et al. (2017) con- 
cluded that $4 \mathrm{~L} / \mathrm{t}$ of formic acid was not sufficient to decrease clostridia activity in lupin-wheat silage when the nitrate concentration of the crop was low. When formic/propionic acid-based additives were applied at $4 \mathrm{~L} / \mathrm{t}$ to soil-contaminated grass-clover silage, butyric acid production by clostridia activity was eliminated (Nadeau and Auerbach, 2014). All of these improvements in silage preservation resulted in decreased DM losses.

Salt-Based Additives. Nitrite-containing additives in various blends with hexamine, benzoate, sorbate, propionate, or formate are known to be efficient against clostridia activity in a range of forages differing in fermentation capacity (Knický and Spörndly, 2009, 2011; Nadeau and Auerbach, 2014; Auerbach et al., 2016; König et al., 2017). Results from these studies showed decreased numbers of clostridial spores and decreased concentrations of butyric acid and $\mathrm{NH}_{3}-\mathrm{N}$. Also, when alfalfa, red clover, orchardgrass, and other grass-red clover mixtures were ensiled at low DM contents, silages treated with nitrite-containing additives had higher lactic acid concentrations than untreated silages (Knický and Spörndly, 2009, 2011; Auerbach et al., 2016), indicating along with the butyric acid concentrations that lactate-assimilating clostridia had been present in the untreated silages (Pahlow et al., 2003). When alfalfa and orchardgrass were ensiled at low DM contents, elevated levels of biogenic amines $(6.4 \mathrm{~g} / \mathrm{kg}$ of DM) were found in untreated silages, a response indicative of the decarboxylation of AA by clostridia. Use of nitrite-containing additives in blends with hexamine, formate/sorbate, or formate/benzoate at $3 \mathrm{~L} / \mathrm{t}$ decreased the concentration of biogenic amines to low levels (2.0 to $2.6 \mathrm{~g} / \mathrm{kg}$ of DM; Auerbach et al., 2016). The use of these salt-based additives also decreased DM losses.

Volatile organic compounds, such as alcohols in silages, contribute significantly to air pollution (ozone) by photochemical reactions with nitrogen oxides (Howard et al., 2010). Weiss and Auerbach (2012a) found a strong correlation between concentrations of ethanol and ethyl esters in 524 laboratory silages of corn, wheat, sorghum and grass $\left(\mathrm{R}^{2}=0.90\right)$, where each incremental increase in ethanol by $5 \mathrm{~g} / \mathrm{kg}$ of DM increased total ethyl ester concentration by about $100 \mathrm{mg} / \mathrm{kg}$ of DM. Use of additives containing sorbate, benzoate, and mixtures thereof at sufficient dosages decrease ethanol concentrations of corn silage, thereby decreasing the formation of ethyl esters (Weiss et al., 2016). However, formic acid-based additives can stimulate ethanol production and, thereby, ethyl ester formation in corn silage (Weiss and Auerbach, 2012b). This result is crop-specific, as formic acid and a mixture of nitrite/ hexamine decreased the concentrations of ethanol and ethyl esters in lupin/wheat silage (König et al., 2017).

\section{Effects on Aerobic Stability}

Formic/Propionic Acid-Based Additives. Nadeau et al. (2013) reported decreased DM losses and contents of ethanol and yeast by an additive containing formic/propionic/formate/benzoic/sorbic/glycerol at 3 $\mathrm{L} / \mathrm{t}$ in both chopped (27 $\mathrm{mm}$; forage harvester) and cut (85 $\mathrm{mm}$; forage pick-up wagon) grass-clover silage in hard-pressed round bales (32-42\% DM). As the aerobic stability of the cut silage was much higher than in chopped silage of the control treatment (6.7 vs. $2.9 \mathrm{~d}$ ), the additive improved aerobic stability compared with untreated only in chopped silage (11.3 vs. 2.9 d). Similarly, Knický and Spörndly (2009) reported improved aerobic stability of well-fermented grass-clover silage at $45 \% \mathrm{DM}$ by $3.5 \mathrm{~d}$ when a formic/propionic/formate containing additive at $5 \mathrm{~L} / \mathrm{t}$ was used. When the same additive was applied to silage at $22 \%$ DM, no improvement in aerobic stability occurred, as the butyric acid in the untreated silage inhibited yeast activity similarly to that of the additive in the treated silage (Knický and Spörndly, 2009). When a similar additive was used in making whole-crop barley silage, effects on aerobic stability varied depending on chop length and maturity stage of the barley at harvest (Knický, 2005). When ensiling whole-crop corn, Nadeau et al. (2011) showed improved aerobic stability in 2 of 3 maturity stages after 28 and $110 \mathrm{~d}$ of ensiling when a product containing formic, propionic, formate, benzoic, and sorbic acids and glycerol at $4 \mathrm{~L} / \mathrm{t}$ was used. The improved aerobic stability of the treated silages (average of 11.8 compared with $5.7 \mathrm{~d}$ in the untreated silages) prevented any decrease in in vitro rumen OM digestibility in the treated silages over a 14-d aeration period, whereas the digestibility of the untreated decreased from 83 at opening to $76 \%$.

Salt-Based Additives. Buffered propionic acidbased additives and ammonium hydroxide decreased ethanol concentration and improved aerobic stability of corn silage in a dose-dependent manner from 1 to $3 \mathrm{~g} /$ $\mathrm{kg}$ of fresh weight, with the highest concentration resulting in significantly higher aerobic stability than the untreated silage (Kung et al., 2000). When a buffered propionic acid-based additive was applied to barley silage at $2 \mathrm{~g} / \mathrm{kg}$ of fresh weight, levels of butyric acid declined (Kung and Ranjit, 2001; Kung et al., 2004), with a numerical decrease in ethanol content and improved aerobic stability of $244 \mathrm{~h}$ as compared with untreated silage (Kung and Ranjit, 2001). Differences in types of active ingredients included with propionate and differ- 
ences in the concentrations of active ingredients in additives can have a profound effect on ensiling outcomes.

Yeasts were essentially eliminated $\left(10^{1}\right.$ vs. $\left.10^{5} \mathrm{cfu} / \mathrm{g}\right)$ and ethanol content and DM losses decreased, whereas the aerobic stability was increased in both chopped $(27 \mathrm{~mm})$ and cut $(85 \mathrm{~mm})$ grass-clover silage stored in hard-pressed round bales and treated with an additive containing nitrite, hexamine, sorbate, benzoate, and propionate at $2 \mathrm{~L} / \mathrm{t}$ (Nadeau et al., 2013). Various blends of benzoate, sorbate, or propionate in mixture with nitrite at 3 to $5 \mathrm{~L} / \mathrm{t}$ have shown to be effective against yeast activity, resulting in decreased ethanol content and increased aerobic stability in a range of well-fermented, 30 to $45 \%$ DM silages (grass-clover, corn; Knický and Spörndly, 2009, 2011, 2015).

As stated, potassium sorbate is more effective against yeast than sodium benzoate (Auerbach and Nadeau, 2013; Bernardes et al., 2014). To compare products differing in application rates of these active substances, Auerbach and Nadeau (2013) used sodium benzoate equivalents (SBE), assuming potassium sorbate possessed twice the antifungal activity of sodium benzoate (Auerbach, 1996). The SBE, ranging from 0 to $1,100 \mathrm{~g} / \mathrm{t}$ of fresh matter, were positively related to the aerobic stability of corn silage (aerobic stability $\left.=1.77 \mathrm{e}^{0.0018 \times \mathrm{SBE}} ; \mathrm{R}^{2}=0.85, P<0.01, \mathrm{n}=7\right)$. A linear negative relationship existed between yeast count and aerobic stability (aerobic stability $=17.5-4.19$ $\times$ yeast count; $\mathrm{R}^{2}=0.87, P<0.01, \mathrm{n}=7$ ); however, more research needs to be completed to refine the antifungal activity estimates of potassium sorbate and sodium benzoate. For example, when potassium sorbate and sodium benzoate were applied separately at higher rates $(1,000$ and $2,000 \mathrm{~g} / \mathrm{t}$ of fresh matter), their effects on aerobic stability in corn silage were similar, although potassium sorbate was more effective against yeast and mold activity during air exposure (Bernardes et al., 2014).

The effects of potassium sorbate and sodium benzoate on yeast counts, ethanol content, and aerobic stability of corn silage are dose-dependent (Auerbach and Nadeau, 2013; Bernardes et al., 2014; Hafner et al., 2014; Nadeau et al., 2015a). Application of a low level of potassium sorbate to corn silage $(91 \mathrm{mg} / \mathrm{kg}$ of fresh matter) may decrease aerobic stability, as it has been shown to increase yeast count and ethanol content compared with untreated silage (Hafner et al., 2014). In contrast, addition of $1.0 \mathrm{~g}$ of potassium sorbate $/ \mathrm{kg}$ of fresh matter has inhibited yeast growth, resulting in decreased ethanol content (Hafner et al., 2014) and improved aerobic stability of corn silage (Teller et al., 2012; Bernardes et al., 2014). Addition of a product containing sodium benzoate, potassium sorbate, and sodium nitrite in the proportions of 200, 100, and 50 $\mathrm{g} / \mathrm{kg}$, respectively, decreased yeast count and ethanol content resulting in improved aerobic stability after 90 $\mathrm{d}$ of storage when applied at $2 \mathrm{~L} / \mathrm{t}$ to high-moisture corn (i.e., $0.4,0.2$, and $0.1 \mathrm{~g} / \mathrm{kg}$ of fresh matter of sodium benzoate, potassium sorbate, and sodium nitrite, respectively), with no further improvements at 3 and $4 \mathrm{~L} / \mathrm{t}$ of the product (Da Silva et al., 2015). Recent research with this product applied at $2 \mathrm{~L} / \mathrm{t}$ found improvements in aerobic stability of corn silage as soon as $1 \mathrm{~d}$ of ensiling, even though yeast counts were similar between the treated and untreated silages (Da Silva et al., 2017). Furthermore, Nadeau et al. (2011) showed a strong positive effect of a product containing $250 \mathrm{~g}$ of sodium benzoate and $150 \mathrm{~g}$ of potassium sorbate per liter on the aerobic stability of corn silage stored for 28 and $110 \mathrm{~d}$ and harvested at 3 different maturity stages. The improved aerobic stability eliminated the decrease in OM digestibility that was found in the untreated silage during aerobic exposure.

Calcium oxide (lime) has been tested as an additive to sugarcane silage, as it is converted to calcium hydroxide upon reaction with water. Compared with untreated sugarcane silage, studies have shown decreased ethanol content and increased aerobic stability from calcium oxide treatment, but it increased concentrations of $\mathrm{NH}_{3}-\mathrm{N}$ and butyric acid, making it less desirable as a silage additive (Custódio et al., 2016; Jacovaci et al., 2017).

\section{Effects on Animal Performance}

Formic/Propionic Acid-Based Additives. Formic acid restricts fermentation and protein degradation during ensiling, which can have a positive effect on animal performance (Winters et al., 2001). When direct-cut formic acid-treated grass silage $(3.3 \mathrm{~L} / \mathrm{t})$ was fed to 400-kg Charolais $\times$ Friesian steers, DMI increased from 7.4 to $8.4 \mathrm{~kg} / \mathrm{d}$ and daily live weight gain $(\mathbf{L W G}$ ) from 0.67 to $0.94 \mathrm{~kg}$, resulting in an improved feed efficiency ( $\mathrm{kg}$ of LWG/kg of DMI) by $26 \%$ (Winters et al., 2001). The improvement in animal performance was attributed to an improved AA balance by suppression of proteolytic bacteria and plant enzymes. Likewise, compared with untreated alfalfa silage, Broderick et al. (2007) reported decreased proteolysis and, thereby, lower contents of soluble NPN, ammonia- $\mathrm{N}$, and free AA-N in alfalfa silage treated with ammonium tetraformate $(7 \mathrm{~L} / \mathrm{t})$. When fed to dairy cows, the daily DMI increased by $1.0 \mathrm{~kg}$ and the $3.5 \%$ FCM increased by $2.1 \mathrm{~kg}$. Content and yield of milk true protein and nitrogen efficiency in milk $\mathrm{N}$ per unit of $\mathrm{N}$ intake were also increased (Broderick et al., 2007); however, this production response was not observed in a second trial. 
Salt-Based Additives. In an experiment by Agnew and Carson (2000), beef steers (mean BW of $425 \mathrm{~kg}$ ) were fed unwilted grass silage, untreated or treated with a blend of ammonium hexamethanoate, ammonium hexapropionate, and octanoic acid $(6 \mathrm{~L} / \mathrm{t})$ ad libitum and supplemented with concentrates at levels of 0 to 4.5 $\mathrm{kg} / \mathrm{d}$ for $112 \mathrm{~d}$ before slaughter. The additive increased silage intake, which resulted in an increased carcass gain from 0.17 to $0.35 \mathrm{~kg} / \mathrm{d}$ when no concentrate was fed, but the benefits of the additive on DMI decreased as concentrate levels increased. Carcass conformation and fat grade were also higher in steers fed the treated silage (Agnew and Carson, 2000). In a dairy cow experiment, where ammonium propionate at $5 \mathrm{~L} / \mathrm{t}$ was applied to corn silage, no effect on intake or milk yield was observed (Levital et al., 2009). Furthermore, Diaz et al. (2013) found no improvements in diet digestibility, $\mathrm{N}$ balance, LWG, or carcass quality of finishing steers fed ammoniated or untreated high-moisture ear corn. However, compared with untreated silage, Nadeau and Arnesson (2016) reported increased live weight at birth (6.0 vs. $5.2 \mathrm{~kg}$ ) and a tendency for increased LWG until weaning (442 vs. $409 \mathrm{~g} / \mathrm{d}$ ) in lambs suckling ewes fed grass-clover silage treated with an additive, containing sodium nitrite, hexamine, sodium benzoate, potassium sorbate, and sodium propionate applied at $2 \mathrm{~L} / \mathrm{t}$.

The same additive (sodium nitrite, hexamine, sodium benzoate, potassium sorbate, and sodium propionate; 2 $\mathrm{L} / \mathrm{t}$ ) was used on grass-legume silage fed to dairy cows (Nadeau et al., 2014). The additive decreased milk urea content (230 vs. $240 \mathrm{mg} / \mathrm{L} ; P<0.001)$ and tended to increase the excretions of purine derivatives in urine (115 vs. $95 \mathrm{~g} / \mathrm{d}$ ), suggesting an increase in the microbial protein flow to the duodenum. Furthermore, cows fed the treated silage had lower SCC in milk $(52,000$ vs. $92,000$ per $\mathrm{mL} ; P<0.05)$. The improved performance of the cows was attributed to decreased proteolysis and increased sugar content of treated as compared with untreated silage (E. M. G. Nadeau, unpublished data; Nadeau et al., 2014).

In a later experiment (Nadeau et al., 2015b), dairy cows were fed grass-clover silage treated with the same additive or untreated silage in diets differing in RUP ( 4.9 vs. $2.9 \%$ of $\mathrm{DM}$ at $15 \% \mathrm{CP}$ of $\mathrm{DM}$ ). The high-RUP diet had higher milk yield than the low-RUP diet (29.4 vs. $27.9 \mathrm{~kg}$ ), but DMI was not affected by RUP or silage treatment. The additive-treated silage produced higher yields of milk and ECM compared with untreated only in the low-RUP diets (29.1 vs. $26.0 \mathrm{~kg}$ of milk; 30.5 vs. $27.1 \mathrm{~kg}$ of ECM). Similarly, feed efficiency of cows was higher for the additive-treated silage than for the control silage only in the low-RUP diets (1.53 vs. $1.27 \mathrm{~kg}$ of $\mathrm{ECM} / \mathrm{kg}$ of DMI). The improved performance of the cows on additive-treated silage when fed a diet with low
RUP could partly be related to the additive decreasing proteolysis as compared with untreated silage (E. M. G. Nadeau, unpublished data; Nadeau et al., 2015b).

\section{ENZYME ADDITIVES}

\section{Exogenous Enzymes}

A variety of enzyme additives have been added to forage at ensiling in an effort to improve fermentation and the nutritive value of silage. The overwhelming majority of these studies have applied a mixture of cellulases and hemicellulases so as to increase the release of plant cell wall carbohydrates, making them available for LAB to ferment to lactic acid. Enzyme additives are almost invariably applied in combination with bacterial inoculants, making it difficult to differentiate between bacterial versus enzyme-mediated ensiling responses. In studies that enable differentiation, the addition of fibrolytic enzymes to bacterial inoculants has had a positive effect on silage quality, increasing in saccosoluble NDF and improving feed efficiency in feedlot cattle (Zahiroddini et al., 2004). In other studies, less well-defined enzyme cocktails added in conjunction with a complex mixture of inoculants accelerated the post-ensiling decline in $\mathrm{pH}$ but failed to improve the growth performance of steers (Addah et al., 2016). Lynch et al. (2015) added cellulase and xylanase to corn forage before ensiling alone and in combination with a ferulic acid esterase-producing (FAE) silage inoculant and found that the combination resulted in a lower $\mathrm{pH}$ and higher WSC than the control silage after $70 \mathrm{~d}$ of ensiling. However, the enzyme-treated silage also exhibited decreased DM recovery and higher yeast counts, with no indication that the nutritive value of corn silage was improved. Similarly, the addition of this fibrolytic mixture with FAE to alfalfa at ensiling had minimal effects on ensiling and did not improve the nutritive value of alfalfa silage (Lynch et al., 2014). Although fibrolytic enzymes can increase silage digestibility under some circumstances, excessive release of WSC can also decrease aerobic stability, as released sugars are rapidly used by spoilage yeasts and molds (Kung and Muck, 2015). In some instances, enzymes may act on the more-digestible components of NDF, leaving indigestible components intact and thereby lowering the overall digestibility of consumed NDF (Nadeau et al., 2000; Dehghani et al., 2012; Jin et al., 2015). Logically, one would theorize that positive responses to the application of fibrolytic enzymes at ensiling would most likely be with low-WSC forages. This contention was recently supported, as ensiling of a low-WSC forage, Leymus chinensis, with inoculants and a cellulase improved both the fermentation and the 
in vitro digestibility of this wild grass silage (Tian et al., 2014). Similarly, improvements were observed when fibrolytic enzymes were added to mixtures of low-WSC barley straw and corn silage at ensiling (Guo et al., 2014), as well as to high-moisture, low-WSC tropical forages (Khota et al., 2016). Enzymatic profiles and activity of mixed enzyme preparations are often unpredictable, further contributing to the variable responses observed with these additives.

Although enzyme additives aimed at enhancing plant cell wall digestion in silage have been used for decades, only recently has there been an interest in using proteases to hydrolyze the protein matrix within the endosperm of corn to improve the availability of digestible starch in corn silage (Young et al., 2012; Windle et al., 2014). Proteolysis occurs naturally during ensiling (Hoffman et al., 2011), but it requires as much as 10 mo for the protein matrix to be hydrolyzed to an extent that optimizes starch availability in corn silage (Ferraretto et al., 2014). The protein matrix is particularly recalcitrant in late-harvested corn silage, but if starch can be made more available through disruption of the protein matrix by proteases, total harvested DM yield could be increased. Selection of proteases that exhibit superior stability and activity under the low $\mathrm{pH}$ and harsh conditions encountered in silage could potentially further enhance starch availability in corn and sorghum silages, where the vitreous protein matrix can limit starch availability. More research is required to define the optimal concentration of proteases that achieve this response without undue negative effects on silage protein quality and to determine if the economic value gained by improved starch availability offsets the cost of enzyme application.

\section{Bacterial Production of Enzymes}

An alternative approach to adding exogenous enzymes to forage is to select for LAB or other bacterial species that endogenously possess the enzyme activity of interest, as is the case with a strain of Lb. buchneri specifically selected for FAE activity (Nsereko et al., 2008).

Ferulic acid forms ester linkages with sugars within the plant cell wall, one of the primary limiting factors of plant cell wall digestion (Badhan et al., 2014; Raffrenato et al., 2017). Inoculation of silage with an FAE-producing strain of $L b$. buchneri increased the cell wall digestibility of corn silage (Kang et al., 2009) and improved the feed efficiency of growing steers fed barley silage (Addah et al., 2012). However, this same inoculant did not improve the feed efficiency of steers fed a finishing diet containing barley silage, possibly because barley silage comprised a much smaller portion of the diet (Addah et al., 2014). However, other studies have also failed to measure any improvement in NDF digestibility of either alfalfa (Lynch et al., 2014) or corn silage (Lynch et al., 2015) ensiled with this inoculant. Levels of ferulic acid activity during ensiling with FAE Lb. buchneri are low (T. A. McAllister, unpublished data), but long-term exposure to even low levels of enzymes that overcome the limitations of plant cell wall digestion could improve NDF digestibility. Alternatively, it is possible that the expression of FAE differs with ensiling conditions and forage type, resulting in inconsistent improvements in plant cell wall digestion. Stability of the expressed enzyme and its ability to suitably interact with the target substrate is another factor that could induce variable responses. Selection of bacterial species with enzyme activities (e.g., cellulases, esterases, proteases, amylases, and cutinases) could generate approaches to further enhance ensiling if they are employed with an appreciation for the dynamics of the ensiling process. Selected bacteria would need to actively express the desired enzymes during the ensiling process at levels that would elicit targeted outcomes. Emerging tools in the fields of metatranscriptomics and metaproteomics may have the potential to measure and quantify these responses to enable selection of bacteria with these desirable properties and result in more consistent and predictable improvements in silage quality (McAllister et al., 2018). An alternative may be to directly express the desired enzyme activities in the forage itself (Badhan et al., 2014; Lambertz et al., 2014), but to be successful such an approach could not compromise overall DM yield and would need to gain public approval for its use as genetically modified feed.

\section{FUTURE OPPORTUNITIES}

Silage additives have been used to address a wide variety of silage management issues. These issues include ensuring a rapid production of lactic acid and a lowering of $\mathrm{pH}$, avoiding clostridial fermentation, reducing yeast populations to make silages more aerobically stable, and improving animal performance. Beyond enhancing these roles, we think the following possibilities hold promise for the future.

\section{Improving Silage Fermentation}

Producers will, on occasion, be forced by weather conditions to ensile crops too wet, creating a situation where clostridial fermentation is more likely a problem. This can be addressed with nitrites, formic acid and its salts, and sorbic acid, as is typical in northern Europe 
where this issue is more common. Homofermentative LAB inoculants, by lowering $\mathrm{pH}$, may be able to help in some, but not all, situations; however, this approach is an indirect one.

Direct inhibition of clostridia by inoculant LAB is certainly an interesting goal. Considerable efforts have been made by different groups to find bacteriocin production in LAB strains that would inhibit clostridia and other detrimental bacteria (e.g., Flythe and Russell, 2004; Marcinakova and Laukova, 2004; De Vuyst and Leroy, 2007). Challenges exist in terms of inhibiting other LAB (Settanni et al., 2005) while at the same time inhibiting a large percentage of clostridial strains or other detrimental species. Even so, this approach needs further research to identify promising strains.

Good silage management can minimize or prevent mycotoxin production in the silo. The potential for production in the silo can be further reduced through the chemical and microbial additives discussed. Unfortunately, in some years, corn and other whole-crop grain crops may contain high levels of mycotoxins at harvest. In such cases, it would be desirable to reduce mycotoxin concentrations in the silo rather than the current approach of using feed additives in the ration. Several possible avenues for silage additives to decrease mycotoxins include microbial strains that convert mycotoxins to safe compounds, binding agents applied at ensiling instead of at feeding, and other enzymes or chemicals to detoxify the mycotoxins.

\section{Enhancing Aerobic Stability}

Improvement of aerobic stability has been an area of considerable research activity, as noted, through the use of obligate heterofermentative LAB, combination inoculants, other inoculants, and chemical additives. Given the importance of preventing aerobic microbial activity, we expect that there will continue to be considerable research to find better and more profitable approaches to improving aerobic stability.

Target goals will depend on the type of additive. The current obligate heterofermentative LAB on the market take approximately 45 to $60 \mathrm{~d}$ before substantially improving aerobic stability. Identifying strains that would improve aerobic stability earlier in the ensiling process would be helpful. Chemical additives should provide a more consistent return on investment than inoculants because chemical additives are less dependent on biological processes during ensiling. However, the higher initial cost compared with that of inoculants may be a barrier to adoption by producers. Thus, finding new compounds or mixtures of the current ones that lower product cost while maintaining good antifungal activity is of the greatest importance.

\section{Improving Animal Performance}

Some of the additives discussed above have a positive effect on animal production, most often indirectly. However, improvements in milk production or milk production efficiency are what producers expect as the primary return on their investment in a silage additive. Unfortunately, we have a poor understanding as to how additives affect intake and milk production. We need research to understand how the current LAB strains, chemicals, and enzymes affect animal performance so that we have targets for selecting improved additives. This is particularly true for bacterial strains that may enhance rumen microbial activity or enzymes that may allow for more rapid or complete digestion of fiber or complex carbohydrates in the rumen or gastrointestinal tract. The search for new enzymes should focus on activities that attack bonds in fiber that are poorly broken by microbial activity in the rumen instead of reducing NDF or ADF content during ensiling.

Nitrogen transformations in the silo affect the availability and efficiency of that $\mathrm{N}$ to the cow. Typically more than half of the true protein in ryegrass and alfalfa, 2 of the most important forages around the world, are degraded primarily by plant proteolytic enzymes to soluble NPN during ensiling, leading to an inefficient use of the silage $\mathrm{N}$ by cattle. Reduced proteolysis occurs naturally in some forages, such as legumes containing tannins (Albrecht and Muck, 1991) and red clover with its polyphenol oxidase/o-diphenol (PPO) system (Jones et al., 1995). Multiple possible means exist for taking advantage of the differences in forages to aid in preserving alfalfa or ryegrass protein during ensiling. A direct approach would be to genetically engineer alfalfa or ryegrass to produce tannins or the PPO system. Mixtures of forages at ensiling may be useful and provide positive associative benefits (e.g., alfalfa and sainfoin; Wang et al., 2007). Alternatively, tannins or the PPO system may one day be available as additives for ensiling of alfalfa, ryegrass, and other forages to limit true protein loss during ensiling.

In corn, the protein matrix around the starch granules in kernels inhibits ruminal starch digestion. Proteolysis during silo storage slowly breaks the protein matrix so that starch digestibility increases with storage time (Hoffman et al., 2011), as discussed above. Several studies (Young et al., 2012; Windle et al., 2014) have shown that acidic proteases applied at ensiling are able to increase proteolytic activity and improve ruminal starch digestion. Whereas these studies are promising, significant hurdles still exist to the development of an additive that would improve starch digestion in corn silage or high-moisture corn that has been stored for only a few months. 
These are some of the most obvious directions for improving current additives and forecasting what new additives may be on the horizon. As we better understand dairy cattle nutrition and the influence of the interactions between the cow and the microflora in the rumen and lower gastrointestinal tract, new opportunities may arise for silage additives to enhance the feed value of silage. These opportunities may be direct ones, such as improving the balance of AA or providing other nutrients that limit ruminant productivity. Alternatively, they may be indirect ones, such as inhibiting detrimental microorganisms or enhancing beneficial microorganisms in the gastrointestinal tract. Such opportunities may one day lead to silage additives with the potential of making silage of better nutritional value than the harvested crop.

\section{REFERENCES}

Addah, W., J. Baah, and T. A. McAllister. 2016. Effects of an exogenous enzyme-containing inoculant on fermentation characteristics of barley silage and on growth performance of feedlot steers. Can. J. Anim. Sci. 96:1-10.

Addah, W., J. Baah, E. K. Okine, and T. A. McAllister. 2012. A thirdgeneration esterase inoculant alters fermentation pattern and improves aerobic stability of barley silage and the efficiency of body weight gain of growing feedlot cattle. J. Anim. Sci. 90:1541-1552.

Addah, W., J. Baah, E. K. Okine, F. N. Owens, and T. A. McAllister. 2014. Effects of chop-length and a ferulic acid esterase-producing inoculant on fermentation and aerobic stability of barley silage, and growth performance of finishing feedlot steers. Anim. Feed Sci. Technol. 197:34-46.

Adesogan, A. T. 2008. Effect of applying bacterial inoculants to corn silage on the performance of dairy cattle. Lallemand Animal Nutrition Internal Report. Lallemand Animal Nutrition, Milwaukee, WI.

Adesogan, A. T., and M. B. Salawu. 2004. Effect of applying formic acid, heterolactic bacteria or homolactic and heterolactic bacteria on the fermentation of bi-crops of peas and wheat. J. Sci. Food Agric. 84:983-992.

Agnew, R. E., and M. T. Carson. 2000. The effect of a silage additive and level of concentrate supplementation on silage intake, animal performance and carcass characteristics of finishing beef cattle. Grass Forage Sci. 55:114-124.

Albrecht, K. A., and R. E. Muck. 1991. Proteolysis in ensiled forage legumes that vary in tannin concentration. Crop Sci. 31:464-469.

Amado, I. R., C. Fucinõs, P. Fajardo, N. P. Guerra, and L. Pastrana. 2012. Evaluation of two bacteriocin-producing probiotic lactic acid bacteria as inoculants for controlling Listeria monocytogenes in grass and maize silages. Anim. Feed Sci. Technol. 175:137-149.

Arriola, K. G., S. C. Kim, and A. T. Adesogan. 2011. Effect of applying inoculants with heterolactic or homolactic and heterolactic bacteria on the fermentation and quality of corn silage. J. Dairy Sci. 94:1511-1516.

Arriola, K. G., O. C. M. Queiroz, J. J. Romero, D. Casper, E. Muniz, J. Hamie, and A. T. Adesogan. 2015. Effect of microbial inoculants on the quality and aerobic stability of bermudagrass round-bale haylage. J. Dairy Sci. 98:478-485

Assis, F. G. V., C. L. S. Avila, J. C. Pinto, and R. F. Schwan. 2014 New inoculants on maize silage fermentation. Rev. Bras. Zootec. 43:395-403.

Auerbach, H. 1996. Verfahrensgrundlagen zur Senkung des Risikos eines Befalls von Silagen mit Penicillium roqueforti und einer Kontamination mit Mykotoxinen dieses Schimmelpilzes (Technological measures to minimize the risk of the contamination of silages with Penicillium roqueforti and its mycotoxins). Landbauforschung Völkenrode Sonderheft 168:1-167. [In German].

Auerbach, H., and E. Nadeau. 2013. Effects of chemical additives on whole crop maize silage traits. Pages $736-737$ in Proc. 22nd Int. Grassl. Congr. Sept. 15-19, Sydney, New South Wales, Australia. D. L. Michalk, G. D. Millar, W. B. Badgery, and K. M. Broadfoot, ed. New South Wales Department of Primary Industry, Orange, New South Wales, Australia.

Auerbach, H., E. Nadeau, K. Weiss, and P. Theobald. 2016. Effects of different sodium nitrite-containing additives on dry matter losses, fermentation pattern and biogenic amine formation in lucerne and cocksfoot silage. Pages 117-118 in Proc. 17th Int. Conf. Forage Conserv., Horný Smokovec, Slovak Republic, September 27-29. L. Rajcáková, ed. Nat. Agric. Food Centre, Luzianky, Slovak Republic.

Auerbach, H., K. Weiss, and E. Nadeau. 2012. Benefits of using silage additives. Pages 75-144 in Proc. 1st Int. Silage Summit, Leipzig, Saxony, Germany. H. Auerbach, C. Luckstadt, and F. Weissbach, ed. Anytime Publishing Services, Worthington, UK.

Ávila, C. L. S., B. F. Carvalho, J. C. Pinto, W. F. Duarte, and R. F. Schwan. 2014. The use of Lactobacillus species as starter cultures for enhancing the quality of sugar cane silage. J. Dairy Sci 97:940-951.

Badhan, A., J. Lin, Y. Wang, S. Han, K. Kowalczys, D. C. W. Brown, C. J. Ayala, M. Latoszek-Green, B. Miki, A. Tsang, and T. McAllister. 2014. Expression of a fungal ferulic acid esterase in alfalfa modifies cell wall digestibility. Biotechnol. Biofuels 7:39.

Bernardes, T. F., I. L. De Oliviera, M. A. S. Lara, D. R. Casagrande, C. L. S. Ávila, and O. G. Pereira. 2014. Effects of potassium sorbate and sodium benzoate at two application rates on fermentation and aerobic stability of maize silage. Grass Forage Sci. 70:491-498.

Broberg, A., K. Jacobsson, K. Ström, and J. Schnürer. 2007. Metabolite profiles of lactic acid bacteria in grass silage. Appl. Environ. Microbiol. 73:5547-5552.

Broderick, G. A., A. F. Brito, and J. J. Olmos Colmenero. 2007. Effects of feeding formate-treated alfalfa silage or red clover silage on the production of lactating dairy cows. J. Dairy Sci. 90:1378-1391.

Conaghan, P., P. O'Kiely, and F. P. O'Mara. 2011. Possibilities of increasing the residual water-soluble carbohydrate concentration and aerobic stability of low dry-matter perennial ryegrass silage through additive and cultivar use. Grass Forage Sci. 67:177-198.

Contreras-Govea, F. E., R. E. Muck, D. R. Mertens, and P. J. Weimer. 2011. Microbial inoculant effects on silage and in vitro ruminal fermentation, and microbial biomass estimation for alfalfa, BMR corn, and corn silages. Anim. Feed Sci. Technol. 163:2-10.

Costa, D. M., V. C. de Souza, L. A. Fernandez, A. de Oliveira Dos Santos, R. F. Schwan, and C. L. da Silva Avila. 2017. Screening of lactic acid bacteria for enhancing quality of corn silage. PS061. July 24-28. Ann. Soc. Brasileira de Zootecnia. Foz do Iguacu, Brazil.

Custódio, L., G. Morais, J. L. P. Daniel, T. Pauly, and L. G. Nussio. 2016. Effects of chemical and microbial additives on clostridium development in sugarcane (Saccharum officinarum L.) ensiled with lime. Grassl. Sci. 62:135-143.

Da Silva, E. B., R. M. Savage, S. A. Polukis, M. L. Smith, A. M. Gray, R. N. Mester, and L. Kung Jr. 2017. Effectiveness of a chemical additive on improving the aerobic stability of corn silage after short periods of ensiling. J. Dairy Sci. 100(Suppl. 2):263. (Abstr.)

Da Silva, T. C., M. L. Smith, A. M. Barnard, and L. Kung Jr. 2015. The effect of a chemical additive on the fermentation and aerobic stability of high-moisture corn. J. Dairy Sci. 98:8904-8912.

Daniel, J. L. P., M. Checolli, J. Zwielehner, D. Junges, J. Fernandes, and L. G. Nussio. 2015. The effects of Lactobacillus kefiri and L. brevis on the fermentation and aerobic stability of sugarcane silage. Anim. Feed Sci. Technol. 205:69-74.

Danner, H., M. Holzer, E. Mayrhuber, and R. Braun. 2003. Acetic acid increases stability of silage under aerobic conditions. Appl Environ. Microbiol. 69:562-567.

Daughtry, K. V. 2015. Phenotypic and genotypic characterization of Lactobacillus buchneri strains isolated from spoiled, fermented cu- 
cumber. MS Thesis. Department of Food Science, North Carolina State University, Raleigh.

De Vuyst, L., and F. Leroy. 2007. Bacteriocins from lactic acid bacteria: Production, purification, and food applications. J. Mol. Microbiol. Biotechnol. 13:194-199.

Dehghani, M. R., M. R. Weisbjerga, T. Hvelplunda, and N. B. Kristensen. 2012. Effect of enzyme addition to forage at ensiling on silage chemical composition and NDF degradation characteristics. Livest. Sci. 150:51-58.

Diaz, E., D. R. Ouellet, A. Amyot, R. Berthiaume, and M. C. Thivierge. 2013. Effect of inoculated or ammoniated high-moisture ear corn on finishing performance of steers. Anim. Feed Sci. Technol. $182: 25-32$

Driehuis, F., S. J. W. H. Oude Elferink, and S. F. Spoelstra. 1999. Anaerobic lactic acid degradation during ensilage of whole-crop maize inoculated with Lactobacillus buchneri inhibits yeast growth and improves aerobic stability. J. Appl. Microbiol. 87:583-594.

Driehuis, F., S. J. W. H. Oude Elferink, and P. G. Van Wikselaar. 2001. Fermentation characteristics and aerobic stability of grass silage inoculated with Lactobacillus buchneri, with or without homofermentative lactic acid bacteria. Grass Forage Sci. 56:330-343.

Duniere, L., L. Jin, B. Smiley, M. Qi, W. Rutherford, Y. Wang, and T. McAllister. 2015. Impact of adding Saccharomyces strains on fermentation, aerobic stability, nutritive value, and select lactobacilli populations in corn silage. J. Anim. Sci. 93:2322-2335.

Ellis, J. L., A. Bannink, I. K. Hindrichsen, R. D. Kinley, W. F. Pellikaan, N. Milora, and J. Dijkstra. 2016a. The effect of lactic acid bacteria included as a probiotic or silage inoculant on in vitro rumen digestibility, total gas and methane production. Anim. Feed Sci. Technol. 211:61-74.

Ellis, J. L., I. K. Hindrichsen, G. Klop, R. D. Kinley, N. Milora, A. Bannink, and J. Dijkstra. 2016b. Effects of lactic acid bacteria silage inoculation on methane emission and productivity of Holstein Friesian dairy cattle. J. Dairy Sci. 99:7159-7174.

Feichtinger, M., S. Mayrhofer, W. Kneifel, and K. J. Domig. 2016. Tetracycline resistance patterns of Lactobacillus buchneri group strains. J. Food Prot. 79:1741-1747.

Ferraretto, L. F., K. Taysom, D. M. Tasom, R. D. Shaver, and P. C. Hoffman. 2014. Relationships between dry matter content, ensiling, ammonia-nitrogen and ruminal in vitro starch digestibility in high-moisture corn samples. J. Dairy Sci. 97:3221-3227.

Ferreira, D. J., R. P. Lana, A. M. Zanine, E. M. Santos, C. M. Veloso, and G. A. Ribeiro. 2013. Silage fermentation and chemical composition of elephant grass inoculated with rumen strains of Streptococcus bovis. Anim. Feed Sci. Technol. 183:22-28.

Filya, I. 2003. The effect of Lactobacillus buchneri, with or without homofermentative lactic acid bacteria, on the fermentation, aerobic stability and ruminal degradability of wheat, sorghum and maize silages. J. Appl. Microbiol. 95:1080-1086.

Filya, I., E. Sucu, and A. Karabulut. 2004. The effect of Propionibacterium acidipropionici, with or without Lactobacillus plantarum, on the fermentation and aerobic stability of wheat, sorghum and maize silages. J. Appl. Microbiol. 97:818-826.

Filya, I., E. Sucu, and A. Karabulut. 2006. The effect of Lactobacillus buchneri on the fermentation, aerobic stability and ruminal degradability of maize silage. J. Appl. Microbiol. 101:1216-1223.

Flythe, M. D., and J. B. Russell. 2004. The effect of $\mathrm{pH}$ and a bacteriocin (bovicin HC5) on Clostridium sporogenes MD1, a bacterium that has the ability to degrade amino acids in ensiled plant materials. FEMS Microbiol. Ecol. 47:215-222.

Gandra, J. R., E. R. Oliveira, C. S. Takiya, R. H. T. B. Goes, P. G. Paiva, K. M. P. Oliveira, E. R. S. Gandra, N. D. Orbach, and H. M. C. Haraki. 2016. Chitosan improves the chemical composition, microbiological quality, and aerobic stability of sugarcane silage. Anim. Feed Sci. Technol. 214:44-52.

Ganzorig, O., F. Sumisa, B. Batdorj, and T. Yoshida. 2016. Isolation and identification of new lactic acid bacteria with potent biological activity and yeasts in airag, a traditional Mongolian fermented beverage. Food Sci. Technol. Res. 22:575-582.

Guo, G., X. Yuan, L. Li, A. Wen, and T. Shao. 2014. Effects of fibrolytic enzymes, molasses and lactic acid bacteria on fermentation quality of mixed silage of corn and hulless-barley straw in the Tibetan plateau. Grassl. Sci. 60:240-246.

Hafner, S. D., R. B. Franco, L. Kung Jr., C. A. Rotz, and F. Mitloehner. 2014. Potassium sorbate reduces production of ethanol and 2 esters in corn silage. J. Dairy Sci. 97:7870-7878.

Hammes, W. P., and C. Hertel. 2009. Genus Lactobacillus beijerinck 1901, 212AL. The Firmicutes. Pages 465-490 in Bergey's Manual of Systematic Bacteriology. 2nd Ed. Vol. 3. P. De Vos, G. M. Garrity, D. Jones, N. R. Krieg, W. Ludwig, F. A. Rainey, K. Schleifer, and W. B. Whitman, ed. Springer, New York, NY.

Hoffman, P. C. N. M. Esser, R. D. Shaver, W. K. Coblentz, M. P. Scott, A. L. Bodnar, R. J. Schmidt, and R. C. Charley. 2011. Influence of ensiling time and inoculation on alteration of the starchprotein matrix in high-moisture corn. J. Dairy Sci. 94:2465-2474.

Hofherr, M. W.. L. J. Reich, M. C. Der Bedrosian, M. C. Santos, W. $\mathrm{Hu}$, and L. Kung Jr. 2008. Effect of a microbial inoculant producing ferulic acid esterase on the fermentation and NDF digestibility of normal and BMR corn silages. J. Dairy Sci. 91(E-Suppl. 1):32. (Abstr.)

Howard, C. J., A. Kumar, I. Malkina, F. Mitloehner, P. G. Green, R. G. Flocchini, and M. J. Kleeman. 2010. Reactive organic gas emissions from livestock feed contribute significantly to ozone production in central California. Environ. Sci. Technol. 44:2309-2314.

Huisden, C. M., A. T. Adesogan, S. C. Kim, and T. Ososanya. 2009. Effect of applying molasses or inoculants containing homofermentative or heterofermentative bacteria at two rates on the fermentation and aerobic stability of corn silage. J. Dairy Sci. 92:690-697.

Jacovaci, F. A., C. C. Jobim, P. Schmidt, L. G. Nussio, and J. L. P. Daniel. 2017. A data-analysis on the conservation and nutritive value of sugarcane silage treated with calcium oxide. Anim. Feed Sci. Technol. 225:1-7.

Jalc, D., A. Laukova, Z. Varadyova, P. Homolka, and V. Koukolova. 2009. Effect of inoculated grass silage on rumen fermentation and lipid metabolism in an artificial rumen (RUSITEC). Anim. Feed Sci. Technol. 151:55-64.

Jatkauskas, J., and V. Vrotniakiene. 2011. The effects of silage inoculants on the fermentation and aerobic stability of legume-grass silage. Žemdirbystè-Agriculture 98:367-374.

Jin, L., L. Duniere, J. P. Lynch, T. A. McAllister, J. Baah, and Y. Wang. 2015. Impact of ferulic acid esterase producing lactobacilli and fibrolytic enzymes on conservation characteristics, aerobic stability and fiber digestibility of barley silage. Anim. Feed Sci. Technol. 207:62-74

Jin, L., L. Duniere, J. P. Lynch, R. Zaheer, K. Turkington, R. E. Blackshaw, N. Z. Lupwayi, J. T. O'Donovan, K. N. Harker, T. McAllister, J. Baah, and Y. Wang. 2017. Impact of ferulic acid esterase-producing lactobacilli and fibrolytic enzymes on ensiling and digestion kinetics of mixed small-grain silage. Grass Forage Sci. 72:80-92.

Johanningsmeier, S. D., and R. F. McFeeters. 2013. Metabolism of lactic acid in fermented cucumbers by Lactobacillus buchneri and related species, potential spoilage organisms in reduced salt fermentations. Food Microbiol. 35:129-135

Jones, B. A., R. E. Muck, and R. D. Hatfield. 1995. Red clover extracts inhibit legume proteolysis. J. Sci. Food Agric. 67:329-333.

Jones, B. A., R. E. Muck, and S. C. Ricke. 1991. Selection and application of Streptococcus bovis as a silage inoculant. Appl. Environ. Microbiol. 57:3000-3005.

Kang, T. W., A. T. Adesogan, S. C. Kim, and S. S. Lee. 2009. Effects of an esterase-producing inoculant on fermentation, aerobic stability, and neutral detergent fiber digestibility of corn silage. J. Dairy Sci. 92:732-738.

Keles, G., P. O'Kiely, and P. D. Forristal. 2010. A note on the conservation characteristics of baled grass silages ensiled with different additives. Ir. J. Agric. Food Res. 49:81-86.

Kendall, C., D. K. Combs, and P. C. Hoffman. 2002. Performance of dairy cattle fed high moisture shelled corn inoculated with Lactobacillus buchneri. J. Dairy Sci. 85(Suppl. 1):385. (Abstr.)

Khota, W., S. Pholsen, D. Higgs, and Y. Cai. 2016. Natural lactic acid bacteria population of tropical grasses and their fermentation 
factor analysis of silage prepared with cellulase and inoculant. J. Dairy Sci. 99:9768-9781.

Kleinschmit, D. H., and L. Kung Jr. 2006a. A meta-analysis of the effects of Lactobacillus buchneri on the fermentation and aerobic stability of corn and grass and small-grain silages. J. Dairy Sci. 89:4005-4013.

Kleinschmit, D. H., and L. Kung Jr. 2006b. The effects of Lactobacillus buchneri 40788 and Pediococcus pentosaceus R1094 on the fermentation of corn silage. J. Dairy Sci. 89:3999-4004.

Kleinschmit, D. H., R. J. Schmidt, and L. Kung Jr. 2005. The effects of various antifungal additives on the fermentation and aerobic stability of corn silage. J. Dairy Sci. 88:2130-2139.

Knický, M. 2005. Possibilities to improve silage conservation. PhD thesis. Faculty of Veterinary Medicine and Animal Science, Department of Animal Nutrition and Management, Swedish University of Agricultural Sciences, Uppsala, Sweden.

Knický, M., and R. Spörndly. 2009. Sodium benzoate, potassium sorbate and sodium nitrite as silage additives. J. Sci. Food Agric. 89:2659-2667.

Knický, M., and R. Spörndly. 2011. The ensiling capability of a mixture of sodium benzoate, potassium sorbate, and sodium nitrite. J. Dairy Sci. 94:824-831.

Knický, M., and R. Spörndly. 2015. Use of a mixture of sodium nitrite sodium benzoate, and potassium sorbate in aerobically challenged silages. J. Dairy Sci. 98:5729-5734.

König, W., M. Lamminen, K. Weiss, T. T. Tuomivirta, S. S. Muñoz, H. Fritze, K. Elo, L. Puhakka, A. Vanhatalo, and S. Jaakkola. 2017. The effect of additives on the quality of white lupin-wheat silage assessed by fermentation pattern and $\mathrm{qPCR}$ quantification of clostridia. Grass Forage Sci. 72:757-771.

Kristensen, N. B., K. H. Sloth, O. Højberg, N. H. Spliid, C. Jensen, and R. Thøgersen. 2010. Effects of microbial inoculants on corn silage fermentation, microbial contents, aerobic stability, and milk production under field conditions. J. Dairy Sci. 93:3764-3774.

Krooneman, J., F. Faber, A. C. Alderkamp, S. J. H. W. Oude Elferink, F. Driehuis, I. Cleenwerck, J. Swings, J. C. Gottschal, and M. Vancanneyt. 2002. Lactobacilllus diolivorans sp. Nov., a 1,2 propanediol-degrading bacterium isolated from aerobically stable maize silage. Int. J. Syst. Evol. Microbiol. 52:639-646.

Kung, L., Jr., and R. E. Muck. 2015. Silage additives: Where are we going? Pages $72-81$ in Proc. XVII Int. Silage Conf., Piracicaba Sao Paulo, Brazil. J. L. P. Daniel, G. Morais, D. Junges, and L. G. Nussio, ed. University of Sao Paulo, Piracicaba, SP, Brazil.

Kung, L., Jr., C. L. Myers, J. M. Neylon, C. C. Taylor, J. Lazartic, J. A. Mills, and A. G. Whiter. 2004. The effects of buffered propionic acid-based additives alone or combined with microbial inoculation on the fermentation of high moisture corn and whole-crop barley. J. Dairy Sci. 87:1310-1316.

Kung, L., Jr., and N. K. Ranjit. 2001. The effect of Lactobacillus buchneri and other additives on the fermentation and aerobic stability of barley silages. J. Dairy Sci. 84:1149-1155.

Kung, L., Jr., J. R. Robinson, N. K. Ranjit, J. H. Chen, C. M. Golt, and J. D. Pesek. 2000. Microbial populations, fermentation endproducts, and aerobic stability of corn silage treated with ammonia or a propionic acid-based preservative. J. Dairy Sci. 83:1479-1486.

Kung, L., Jr., M. Santos, and M. DerBedrosian. 2010. The effect of feeding cows corn silage with or without L. buchneri 40788 and supplemented with or without Levucell SC. Lallemand Animal Nutrition Internal Report. Lallemand Animal Nutrition, Milwaukee, WI.

Kung, L., Jr., M. R. Stokes, and C. J. Lin. 2003a. Silage additives, Pages 305-360 in Silage Science and Technology. D. R. Buxton, R. E. Muck, and R. E. Harrison, ed. Amer. Soc. Agron., Crop Sci. Soc. Amer., Soil Sci. Soc. Amer., Madison, WI.

Kung, L. Jr., C. C. Taylor, M. P. Lynch, and J. M. Neylon. 2003b. The effect of treating alfalfa with Lactobacillus buchneri 40788 on silage fermentation, aerobic stability, and nutritive value for lactating dairy cows. J. Dairy Sci. 86:336-343.

Lambertz, C., M. M. Garvey, J. Klinger, D. Heesel, H. Klose, R. Fisher, and U. Commandeur. 2014. Challenges and advances in the heterologous expression of cellulolytic enzymes: A review. Biotechnol. Biofuels 7:135.

Lara, E. C., F. C. Basso, F. B. de Assis, F. A. Souza, T. T. Berchielli, and R. A. Reis. 2016. Changes in the nutritive value and aerobic stability of corn silages inoculated with Bacillus subtilis alone or combined with Lactobacillus plantarum. Anim. Prod. Sci. $56: 1867-1874$

Lee, H. A., Jr., and R. H. Abeles. 1963. Purification and properties of dioldehydrase, an enzyme requiring a cobamide coenzyme. J. Biol. Chem. 238:2367-2373.

Levital, T., A. F. Mustafa, P. Seguin, and G. Lefebvre. 2009. Effects of a propionic acid-based additive on short-term ensiling characteristics of whole plant maize and on dairy cow performance. Anim. Feed Sci. Technol. 152:21-32.

Lindqvist, H., E. Nadeau, and S. K. Jensen. 2011. Alpha-tocopherol and $\beta$-carotene in legume grass mixtures as influenced by wilting, ensiling and type of silage additive. Grass Forage Sci. 67:119-128.

Liu, Q. H., F. Y. Yang, J. G. Zhang, and T. Shao. 2014. Characteristics of Lactobacillus parafarraginis ZH1 and its role in improving the aerobic stability of silages. J. Appl. Microbiol. 117:405-416.

Lynch, J. P., J. Baah, and K. A. Beauchemin. 2015. Conservation, fiber digestibility, and nutritive value of corn harvested at 2 cutting heights and ensiled with fibrolytic enzymes, either alone or with a ferulic acid esterase-producing inoculant. J. Dairy Sci. 98:1214-1224.

Lynch, J. P., J. Lin, E. C. Lara, J. Baah, and K. A. Beauchemin. 2014. The effect of exogenous fibrolytic enzymes and a ferulic acid esterase-producing inoculant on the fibre degradability, chemical composition and conservation characteristics of alfalfa silage. Anim. Feed Sci. Technol. 193:21-31.

Marcinakova, M., and A. Laukova. 2004. Probiotic properties of Enterococcus faecium ef9296 strain isolated from silage. Acta Vet. Brno 73:513-519.

Mari, L. J., R. J. Schmidt, L. G. Nussio, C. M. Hallada, and L. Kung Jr. 2009. An evaluation of the effectiveness of Lactobacillus buchneri 40788 to alter fermentation and improve the aerobic stability of corn silage in farm silos. J. Dairy Sci. 92:1174-1176.

McAllister, T. A., L. Duniere, P. Drouin, S. Xu, Y. Wang, K. Munns, and R. Zaheer. 2018. Using molecular approaches to define the microbial ecology of silage. J. Dairy Sci. 101:4060-4074. https:// doi.org/10.3168/jds.2017-13703.

McDonald, P., A. R. Henderson, and S. J. E. Heron. 1991. The Biochemistry of Silage. Chalcombe Publications, Marlow, UK.

Muck, R. E. 1996. A lactic acid bacteria strain to improve aerobic stability of silages. Pages 42-43 in 1996 U.S. Dairy Forage Research Center 1996 Research Summaries. U.S. Dairy Forage Res. Ctr., Madison, WI.

Muck, R. E. 2004. Effects of corn silage inoculants on aerobic stability. Trans. ASAE 47:1011-1016.

Muck, R. E., and L. Kung Jr. 1997. Effects of silage additives ensiling. Pages 187-199 in Proc. Silage: Field to Feedbunk. NRAES-99. Natural Resource, Agriculture, and Engineering Service, Ithaca, NY.

Muck, R. E., Z. G. Weinberg, and F. E. Contreras-Govea. 2013. Silage extracts used to study the mode of action of silage inoculants in ruminants. Agric. Food Sci. 22:108-114.

Nadeau, E. 2007. Effects of plant species, stage of maturity and additive on the feeding value of whole-crop cereal silage. J. Sci. Food Agric. 87:789-801.

Nadeau, E., and A. Arnesson. 2016. Intake and performance of ewes and lambs fed grass-clover silage treated with chemical additives. Grassl. Sci. Eur. 21:479-481.

Nadeau, E., A. Arnesson, J. Jakobsson, and H. Auerbach. 2015a. Chemical additives reduce yeast count and enhance aerobic stability in high dry matter corn silage. Pages $354-355$ in Proc. XVII Int. Silage Conf., Piracicaba, Sao Paulo, Brazil. J. L. P. Daniel, G. Morais, D. Junges, and L. G. Nussio, ed. University of Sao Paulo, Piracicaba, SP, Brazil.

Nadeau, E., and H. Auerbach. 2014. Effects of particle size and chemical additives on fermentation and aerobic stability of grass-clover silage. Pages 19-24 in Proc. 5th Nordic Feed Sci. Conf., Uppsala, 
Sweden. Report 290, Department of Animal Nutrition and Management, Swedish University of Agricultural Sciences, Uppsala, Sweden.

Nadeau, E., O. Hallin, H. Auerbach, J. Jakobsson, and A. Arnesson. 2013. Quality of baled grass-clover silage as affected by additives and harvest methods. Pages 744-745 in Proc. 22nd Int. Grassl. Congr., Sydney, NSW, Australia. D. L. Michalk, G. D. Millar, W. B. Badgery, and K. M. Broadfoot, ed. New South Wales Department of Primary Industry, Orange, NSW, Australia.

Nadeau, E., B. Johansson, W. Richardt, and M. Murphy. 2015b. Protein quality of grass silage as affected by silage additives and its effects on dairy cow performance. J. Dairy Sci. 98(Suppl. 2):206. (Abstr.).

Nadeau, E., B. Johansson, W. Richardt, M. Murphy, and H. Auerbach. 2014. Protein quality of grass silage and its effects on dairy cow performance. Page 210 in Proc. Aust. Soc. Anim. Prod. Vol. 30. Joint ISNH/ISRP, Canberra, Australia. Australian Society of Animal Production, Wagga Wagga, NSW, Australia.

Nadeau, E., E. Svensson, K. Zaralis, C. Helander, T. Pauly, and A. Arnesson. 2011. Effects of additive on aerobic stability and nutritive value of maize silage stored during different time periods when harvested at advancing maturity stages. Page 393 in Advances in Animal Biosciences, vol. 2, Proc. 8th Int. Symp. Nutr. Herbiv., Aberythwyth, Wales. Cambridge University Press, Cambridge, UK.

Nadeau, E. M. G., J. R. Russell, and D. R. Buxton. 2000. Intake, digestibility, and composition of orchardgrass and alfalfa silages treated with cellulase, inoculant and formic acid for lambs. J. Anim. Sci. 78:2980-2989.

Nkosi, B. D., R. Meeske, D. Palic, T. Langa, K.-J. Leeuw, and I. B. Groenewald. 2009. Effects of ensiling whole crop maize with bacterial inoculants on the fermentation, aerobic stability, and growth performance of lambs. Anim. Feed Sci. Technol. 154:193-203.

Nkosi, B. D., R. Meeske, and H. J. van der Merwe. 2010. Effects of homofermentative and heterofermentative bacterial silage inoculants on potato hash silage fermentation and digestibility in rams. Anim. Feed Sci. Technol. 157:195-200.

Nsereko, V. L., B. K. Smiley, W. M. Rutherford, A. Spielbauer, K. J. Forrester, G. H. Hettinger, E. K. Harman, and B. R. Harman. 2008. Influence of inoculating forage with lactic acid bacterial strains that produce ferulate esterase on ensilage and ruminal degradation of fiber. Anim. Feed Sci. Technol. 145:122-135.

Ok, J. U., S. M. Lee, J. H. Lim, T. W. Kang, H. Y. Jung, Y. H. Moon, and S. S. Lee. 2006. Effect of yeast addition in rice straw silage fermentation. J. Anim. Sci. Technol. 48:691-698.

Oliveira, A. S., Z. G. Weinberg, I. M. Ogunade, A. A. P. Cervantes, K. G. Arriola, Y. Jiang, D. Kim, X. Li, M. C. M. Gonçalves, D. Vyas, and A. T. Adesogan. 2017. Meta-analysis of effects of inoculation with homofermentative and facultative heterofermentative lactic acid bacteria on silage fermentation, aerobic stability, and the performance of dairy cows. J. Dairy Sci. 100:4587-4603.

Olstorpe, M., J. Borling, J. Schnürer, and V. Passoth. 2010. Pichia anomala yeast improved feed hygiene during storage of moist crimped barley grain under Swedish farm conditions. Anim. Feed Sci. Technol. 156:47-56.

Oude Elferink, S. J. W. H., J. Krooneman, J. C. Gottschal, S. F. Spoelstra, F. Faber, and F. Driehuis. 2001. Anaerobic conversion of lactic acid to acetic acid and 1,2-propanediol by Lactobacillus buchneri. Appl. Environ. Microbiol. 67:125-132.

Pahlow, G., R. E. Muck, F. Driehuis, S. J. W. H. Oude Elferink, and S. F. Spoelstra. 2003. Microbiology of ensiling. Pages 31-93 in Silage Science and Technology. D. R. Buxton, R. E. Muck, and R. E. Harrison, ed. Am. Soc. Agron., Crop Sci. Soc. Am., Soil Sci. Soc. Am., Madison, WI.

Pedroso, A. F., L. G. Nussio, W. Barioni Jr., A. A. Rodrigues, D. R. S. Loures, F. de Campos, J. L. Ribero, L. J. Mari, M. Zopollatto, M. Junqueira, P. Schmidt, S. F. Paziani, and J. Horii. 2006. Performance of Holstein heifers fed sugarcane silages treated with urea, sodium benzoate or Lactobacillus buchneri. Pesqui. Agropecu. Bras. 41:649-654.

Polukis, S. A., M. L. Smith, R. M. Savage, E. Benjamim da Silva, A. Laubach, A. Gray, and L. Kung Jr. 2016. The effect of microbial inoculants on the aerobic stability of high moisture corn. J. Dairy Sci. 99(E-Suppl. 1):678. (Abstr.)

Pot, B., and E. Tsakalidou. 2009. Taxonomy and metabolism of Lactobacillus. Pages 3-58 in Lactobacillus Molecular Biology: From Genomics to Probiotics, 1st ed. Å. Ljungh and T. Wadström, ed. Caister Academic Press, Poole, UK.

Queiroz, O. C. M., L. G. Nussio, P. Schmidt, J. L. Ribero, M. C. Santos, and M. Zopollato. 2008. Sugar cane silage as compared to traditional supplemental sources of forage in the performance of high production cows. Rev. Bras. Zootec. 37:358-365.

Rabelo, C. H. S., C. J. Härter, and R. A. Reis. 2016. A meta-analysis: Effects of heterofermentative inoculants applied at different dry matter contents on the fermentation patterns and aerobic stability of sugar cane silages. Pages 141-142 in 17th Int. Conf. Forage Conserv., Horný-Smokovec, Slovak Republic. L. Rajčáková, ed. National Agricultural and Food Centre (NPPC), Luzianky, Slovakia.

Raffrenato, E., R. Fievisohn, K. W. Cotanch, R. J. Grant, L. E. Chase, and M. E. Van Amburgh. 2017. Effect of lignin linkages with other plant cell wall components on in vitro and in vivo neutral detergent fiber digestibility and rate of digestion of grass forages. J. Dairy Sci. 100:8119-8131

Ranjit, N. K., and L. Kung Jr. 2000. The effect of Lactobacillus buchneri, Lactobacillus plantarum, or a chemical preservative on the fermentation and aerobic stability of corn silage. J. Dairy Sci. $83: 526-535$.

Ranjit, N. K., C. C. Taylor, and L. Kung Jr. 2002. Effect of Lactobacillus buchneri 40788 on the fermentation, aerobic stability, and nutritive value of maize silage. Grass Forage Sci. 57:1-9.

Reich, L. J., and L. Kung Jr. 2010. Effects of combining Lactobacillus buchneri 40788 with various lactic acid bacteria on the fermentation and aerobic stability of corn silage. Anim. Feed Sci. Technol. 159:105-109.

Saarisalo, E., T. Jalava, E. Skyttä, A. Haikara, and S. Jaakkola. 2006. Effect of lactic acid bacteria inoculants, formic acid, potassium sorbate and sodium benzoate on fermentation quality and aerobic stability of wilted grass silage. Agric. Food Sci. 15:185-199.

Santos, A. O., C. L. S. Ávila, and R. F. Schwan. 2013. Selection of tropical lactic acid bacteria for enhancing the quality of maize silage. J. Dairy Sci. 96:7777-7789.

Savage, R. M., M. C. Windle, S. D. Johanningsmeier, and L. Kung Jr. 2014. The effects of strains of yeasts or Lactobacillus buchneri 40788 on the fermentation, production of volatile organic compounds (VOCs) and aerobic stability of corn silage. J. Dairy Sci. 97(E Suppl. 1):537-538. (Abstr.)

Schmidt, R., T. Hall, and R. Charley. 2017. The pickle of high-acetic silages. Progressive Dairyman. Accessed Aug. 1, 2017. http://www .progressivedairy.com/topics/feed-nutrition/the-pickle-of-high -acetic-acid-silages.

Schmidt, R. J., W. Hu, J. A. Mills, and L. Kung Jr. 2009. The development of lactic acid bacteria and Lactobacillus buchneri and their effects on the fermentation of alfalfa silage. J. Dairy Sci. 92:5005-5010

Schmidt, R. J., and L. Kung Jr. 2010. The effects of Lactobacillus buchneri with or without a homolactic bacterium on the fermentation and aerobic stability of corn silages made at different locations. J. Dairy Sci. 93:1616-1624.

Schnürer, J., and A. Jonsson. 2011. Pichia anomala J121: A 30-year overnight near success biopreservation story. Antonie van Leeuwenhoek 99:5-12.

Seppälä, A., T. Heikkilä, M. Mäki, and M. Rinne. 2016. Effects of additives on the fermentation and aerobic stability of grass silages and total mixed rations. Grass Forage Sci. 71:458-471.

Settanni, L., O. Massitti, D. Van Sinderen, and A. Corsetti. 2005. In situ activity of a bacteriocin-producing Lactococcus lactis strain. Influence on the interactions between lactic acid bacteria during sourdough fermentation. J. Appl. Microbiol. 99:670-681.

Shao, T., L. Zhang, M. Shimojo, and Y. Masuda. 2007. Fermentation quality of Italian ryegrass (Lolium multiflorum Lam.) silages treated with encapsulated-glucose, glucose, sorbic acid and prefermented juices. Asian-australas. J. Anim. Sci. 20:1699-1704. 
Sofyan, A., L. M. Yusiati, Y. Widyastuti, and R. Utomo. 2011. Microbiological characteristic and fermentability of king grass (Pennisetum hybrid) silage treated by lactic acid bacteria-yeast inoculants consortium combined with rice bran addition. J. Indones. Trop. Anim. Agric. 36:265-272.

Sousa, D. P., W. R. Soares Mattos, L. G. Nussio, L. J. Mari, J. L. Ribeiro, and M. Castilho Santos. 2008. Chemical additive and microbial inoculants effects on the fermentation and on the control of the alcohol production in sugarcane silages. Rev. Bras. Zootec. 37:1564-1572

Sriramulu, D. D., M. Liang, D. Hernandez-Romero, E. Raux-Deery, H. Lunsdorf, J. B. Parsons, M. J. Warren, and M. B. Prentice. 2008. Lactobacillus reuteri DSM 20016 produces cobalamin-dependent dioldehydratase in metabolosomes and metabolizes 1,2-propanediol by disproportionation. J. Bacteriol. 190:4559-4567.

Ström, K., J. Sjögren, A. Broberg, and J. Schnürer. 2002. Lactobacillus plantarum MiLAB 393 produces the antifungal cyclic dipeptides cyclo(L-Phe-L-Pro) and cyclo(L-Phe-trans-4-OH-L-Pro) and 3-phenyllactic acid. Appl. Environ. Microbiol. 68:4322-4327.

Sun. Z., J. Yu, T. Dan, W. Zhang, and H. Zhang. 2014. Phylogenesis and Evolution of lactic acid bacteria. Pages 1-101 in Lactic Acid Bacteria, Fundamentals and Practice. H. Zhang and Y. Cai, ed. Springer Science+Business Media, New York, NY.

Tabacco, E., S. Piano, A. Revello-Chion, and G. Borreani. 2011. Effect of Lactobacillus buchneri LN4637 and Lactobacillus buchneri LN40177 on the aerobic stability, fermentation products, and microbial populations of corn silage under farm conditions. J. Dairy Sci. 94:5589-5598

Taylor, C. C., and L. Kung Jr. 2002. The effect of Lactobacillus buchneri 40788 on the fermentation and aerobic stability of high moisture corn in laboratory silos. J. Dairy Sci. 85:1526-1532.

Taylor, C. C., N. J. Ranjit, J. A. Mills, J. M. Neylon, and L. Kung Jr.. 2002. The effect of treating whole-plant barley with Lactobacillus buchneri 40788 on silage fermentation, aerobic stability, and nutritive value for dairy cows. J. Dairy Sci. 85:1793-1800.

Teller, R. S., R. J. Schmidt, L. W. Whitlow, and L. Kung Jr.. 2012 Effect of physical damage to ears of corn before harvest and treatment with various additives on the concentration of mycotoxins, silage fermentation, and aerobic stability of corn silage. J. Dairy Sci. 95:1428-1436.

Thomas, M. E., J. L. Foster, K. C. McCuistion, L. A. Redmon, and R. W. Jessup. 2013. Nutritive value, fermentation characteristics, and in situ disappearance kinetics of sorghum silage treated with inoculants. J. Dairy Sci. 96:7120-7131.

Tian, J., Y. Yu, Z. Yu, T. Shao, R. Na, and M. Zhao. 2014. Effects of lactic acid bacteria inoculants and cellulase on fermentation quality and in vitro digestibility of Leymus chinensis silage. Grassl. Sci. 60:199-205.

Valerio, F., P. Lavermicocca, M. Pascale, and A. Visconti. 2004. Production of phenyllactic acid by lactic acid bacteria: An approach to the selection of strains contributing to food quality and preservation. FEMS Microbiol. Lett. 233:289-295.
Wang, Y., L. R. Barbieri, B. P. Berg, and T. A. McAllister. 2007. Effects of mixing sainfoin with alfalfa on ensiling, ruminal fermentation and total tract digestion of silage. Anim. Feed Sci. Technol. 135:296-314.

Weinberg, Z. G., and R. E. Muck. 1996. New trends and opportunities in the development and use of inoculants for silage. FEMS Microbiol. Rev. 19:53-68.

Weinberg, Z. G., R. E. Muck, and P. J. Weimer. 2003. The survival of silage inoculant lactic acid bacteria in rumen fluid. J. Appl. Microbiol. 94:1066-1071.

Weinberg, Z. G. G. Szakacs, G. Ashbell, and Y. Hen. 1999. The effect of Lactobacillus buchneri and L. plantarum, applied at ensiling, on the ensiling fermentation and aerobic stability of wheat and sorghum silages. J. Ind. Microbiol. Biotechnol. 23:218-222.

Weiss, K., and H. Auerbach. 2012a. Occurrence of volatile organic compounds and ethanol in different types of silages. Pages 128-129 in Proc. XVI Int. Silage Conf., Hämeenlinna, Finland. K. Kuoppala, M. Rinne, and A. Vanhatalo, ed. MTT Agrifood Research Finland, University of Helsinki, Helsinki, Finland.

Weiss, K. and H. Auerbach. 2012b. The effect of different types of chemical silage additives on DM losses, fermentation pattern, volatile organic compounds (VOC) and aerobic stability of maize silage. Pages 360-361 in Proc. XVI Int. Silage Conf., Hämeenlinna, Finland. K. Kuoppala, M. Rinne, and A. Vanhatalo, ed. MTT Agrifood Research Finland, University of Helsinki, Helsinki, Finland.

Weiss, K., B. Kroschewski, and H. Auerbach. 2016. Effects of air exposure, temperature and additives on fermentation characteristics, yeast count, aerobic stability and volatile organic compounds in corn silage. J. Dairy Sci. 99:8053-8069.

Windle, M. C., N. Walker, and L. Kung Jr. 2014. Effects of exogenous protease on the fermentation and nutritive value of corn silage harvested at different dry matter contents and ensiled for various lengths of times. J. Dairy Sci. 97:3053-3060.

Winters, A. L., R. Fychan, and R. Jones. 2001. Effect of formic acid and a bacterial inoculant on the amino acid composition of grass silage and on animal performance. Grass Forage Sci. 56:181-192.

Woolford, M. K. 1975. Microbiological screening of food preservatives, cold sterilants and specific antimicrobial agents as potential silage additives. J. Sci. Food Agric. 26:226-237.

Young, K. M., M. C. Lim, M. C. Der Bedrosian, and L. Kung Jr. 2012 Effect of exogenous protease enzymes on fermentation and nutritive value of corn silage. J. Dairy Sci. 95:6687-6694.

Zahiroddini, H., J. Baah, W. Absalom, and T. A. McAllister. 2004 Effect of an inoculant and hydrolytic enzymes on fermentation and nutritive value of whole crop barley silage. Anim. Feed Sci. Technol. 117:317-330.

Zielinska, K., A. Fabiszewska, M. Swiatek, and D. SzymanowskaPowalowska. 2017. Evaluation of the ability to metabolize 1,2-propanediol by heterofermentative bacteria of the genus Lactobacillus. Electron. J. Biotechnol. 26:60-83. 